\title{
AtDREB2A-CA Influences Root Architecture and Increases Drought Tolerance in Transgenic Cotton
}

\author{
Maria Eugênia Lisei-de-Sá1,2*, Fabricio B. M. Arraes ${ }^{1,3 *}$, Giovani G. Brito ${ }^{4}$, Magda A. Beneventi1,3, \\ Isabela T. Lourenço-Tessutti ${ }^{1}$, Angelina M. M. Basso' ${ }^{1,5}$, Regina M. S. Amorim¹, Maria C. M. Silva ${ }^{1}$, \\ Muhammad Faheem¹, Nelson G. Oliveira6, Junya Mizoi' ${ }^{7}$ Kazuko Yamaguchi-Shinozaki', \\ Maria Fatima Grossi-de-Sa1,8\# \\ ${ }^{1}$ Embrapa Recursos Genéticos e Biotecnologia, Brasília, Brazil \\ ${ }^{2}$ Empresa de Pesquisa Agropecuária de Minas Gerais, Uberaba, Brazil \\ ${ }^{3}$ Universidade Federal do Rio Grande do Sul, Porto Alegre, Brazil \\ ${ }^{4}$ Embrapa Clima Temperado, Pelotas, Brazil \\ ${ }^{5}$ Universidade de Brasília, Brasília, Brazil \\ ${ }^{6}$ Embrapa Agroenergia, Brasília, Brazil \\ ${ }^{7}$ Japan International Research Center for Agricultural Sciences (JIRCAS), Tsukuba, Japan \\ ${ }^{8}$ Universidade Católica de Brasília, Brasília, Brazil \\ Email:maria-eugenia.sa@colaborador.embrapa.br, fabricio.arraes@gmail.com,giovani.brito@embrapa.br, mabeneventi@gmail.com, \\ isabela.lourenço@embrapa.br, angelina_granger@yahoo.com.br,rmsamorim@yahoo.com.br, mattar@embrapa.br, faheem08@live.com, \\ dr.nelson74@hotmail.com, ajmizoi@mail.ecc.u-tokyo.ac.jp, akys@mail.ecc.u-tokyo.ac.jp,\#fatima.grossi@embrapa.br
}

How to cite this paper: Lisei-de-Sá, M.E., Arraes, F.B.M., Brito, G.G., Beneventi, M.A., Lourenço-Tessutti, I.T., Basso, A.M.M., Amorim, R.M.S., Silva, M.C.M., Faheem, M., Oliveira, N.G., Mizoi, J., Yamaguchi-Shinozaki, K. and Grossi-de-Sa, M.F. (2017) AtDREB2A-CA Influences Root Architecture and Increases Drought Tolerance in Transgenic Cotton. Agricultural Sciences, 8, 1195-1225.

https://doi.org/10.4236/as.2017.810087

Received: September 18, 2017

Accepted: October 28, 2017

Published: October 31, 2017

Copyright $\odot 2017$ by authors and Scientific Research Publishing Inc. This work is licensed under the Creative Commons Attribution International License (CC BY 4.0).

http://creativecommons.org/licenses/by/4.0/

\begin{abstract}
Drought is a major environmental factor limiting cotton (Gossypium hirsutum L.) productivity worldwide and projected climate changes could increase their negative effects in the future. Thus, targeting the molecular mechanisms correlated with drought tolerance without reducing productivity is a challenge for plant breeding. In this way, we evaluated the effects of water deficit progress on AtDREB2A-CA transgenic cotton plant responses, driven by the stress-inducible $r d 29$ promoter. Besides shoot and root morphometric traits, gas exchange and osmotic adjustment analyses were also included. Here, we present how altered root traits shown by transgenic plants impacted on physiological acclimation responses when submitted to severe water stress. The integration of $A t D R E B 2 A-C A$ into the cotton genome increased total root volume, surface area and total root length, without negatively affecting shoot morphometric growth parameters and nor phenotypic evaluated traits. Additionally, when compared to wild-type plants, transgenic plants $\left(17-\mathrm{T}_{0}\right.$ plants and its progeny) highlighted a gradual pattern of phenotypic plasticity to
\end{abstract}


some photosynthetic parameters such as photosynthetic rate and stomatal conductance with water deficit progress. Transgene also promoted greater shoot development and root robustness (greater and deeper root mass) allowing roots to grow into deeper soil layers. The same morpho-physiological trend was observed in the subsequent generation $\left(17.6-\mathrm{T}_{2}\right)$. Our results suggest that the altered root traits shown by transgenic plants are the major contributors to higher tolerance response, allowing the AtDRE2A-CA-cotton plants to maintain elevated stomatal conductance and assimilate rates and, consequently, reducing their metabolic costs involved in the antioxidant responses activation. These results also suggest that these morpho-physiological changes increased the number of reproductive structures retained per plant (26\% higher) when compared with its non-transgenic counterpart. This is the first report of cotton plants overexpressing the AtDRE2A-CA transcription factor, demonstrating a morpho-physiological and yield advantages under drought stress, without displaying any yield penalty under irrigated conditions. The mechanisms by which the root traits influenced the acclimation of the transgenic plants to severe water deficit conditions are also discussed. These data present an opportunity to use this strategy in cotton breeding programs in order to improve drought adaptation toward better rooting features.

\section{Keywords}

Dehydration Responsive Element Binding Factors, Water Deficit Tolerance, Gossypium hirsutum, Physiological Phenotyping, Transcription Factor, Stress-Inducible Promoter

\section{Introduction}

Drought is often the most yield-limiting factor for plants. Water supplies will continue to decrease worldwide as the global population will increase from the current 7 billion to over 9 billion people in 2050 [1]. Along with water scarcity, the rate of land expansion under irrigation is decreasing substantially [2]. Therefore, it is imperative to maximize food production vertically, e.g., to minimize the use of cropland and water use and develop higher-yielding varieties resistant to pests and diseases, as well as more tolerant to future climate scenarios [3] [4]. Facing these global agricultural challenges, there is an urgent need to develop crops with delayed stress-onset to manage risk and increase yield and quality under both optimal and suboptimal conditions.

Cotton is one of the most important fiber crops worldwide and annually generates nearly US $\$ 12$ billion. Its production involves more than 350 million people, from farming to logistics, textile ginning, processing and packaging. Currently, cotton is produced by over 60 countries in five continents and Brazil stands amongst the top five cotton producers globally [5]. Nevertheless, cotton crop has been severely threatened by different biotic and abiotic stresses. Water deficit has been considered one of the main limiting factors to crop harvests 
during the critical season [6].

Various traditional and molecular genetics approaches have been applied to improve drought tolerance. Conventional breeding for water deficit tolerance has had and continues to have success, but it is labor-intensive and time-consuming. These constraints primarily arise due to the complex identification of quantitative trait loci that controls yield, as well as the difficulty to control moisture levels in the field [7] [8] [9], which can lead to increase trial error, decreasing its precision and, consequently, making it difficult to quantify the treatment effects. In contrast, rapid progress in plant biotechnology has opened up new possibilities for creating drought tolerant crops by identifying key genes and introducing them through genetic engineering [10].

Numerous drought-inducible genes have been identified and used as candidate genes in genetic engineering including a number of transcription factors that regulate stress-inducible gene expression [11] [12]. Among them, the dehydration-responsive element binding (DREB) transcription factors from Arabidopsis thaliana have been reported to enhance drought tolerance in transgenic plants [13]. Both DREB1A and DREB2A regulatory proteins bind to the same cis-acting element, $D R E$, present in the promoter of numerous genes activated under water stress. However, these two proteins function in different signal transduction pathways under low-temperature and dehydration stress conditions [14] [15]. The AtDREB1 $A$ gene improves tolerance to cold acclimation and dehydration [16] [17]. On the other hand, the AtDREB2A gene or its constitutively active form $(D R E B 2 A-C A)$ is strongly involved in water deficit response but only slightly involved in freezing tolerance [18] [19]. Afterwards, several DREB genes have been identified in a large number of plant species [20] [21] [22] [23].

Early attempts to develop transgenic plants tolerant to water stress focused on the use of constitutive promoters such as CaMV35S. However, it has been demonstrated that the use of a stress-inducible promoter is important to minimize deleterious side-effects including reduced vegetative growth and delayed flowering [16] [24]. Although promoters that are constitutively expressed at high levels are still widely used, they are not appropriate for all transgenes [10] [25] [26].

In cotton, concurrent efforts to identify appropriate transgene-promoter combinations in suitable backgrounds have been undertaken by several research groups as an alternative to circumvent unfavourable climate conditions (Additional File 1-Table S1) [25]-[39]. These reports demonstrate that these gene products protect cotton under water deficit conditions but none of these genes has been used as commercial traits.

Drought stress lead to a considerable reduction in photosynthetic performance mediated through stress-induced stomatal or non-stomatal limitations [40]. Thus, the evaluation of physiological parameters is very important to discriminate between the effects of these limitations on the plant photosynthetic capacity [41] [42]. Moreover, the assessment of variability in specific traits such 
as root architecture and morphology, water use efficiency and yield components is considered critical, in addition to several other physiological aspects [43].

The current study describes the production of genetically modified cotton plants containing the $A t D R E B 2 A-C A$ gene driven by the $r d 29 \mathrm{~A}$ stress-inducible promoter. Our morpho-physiological data demonstrate that the over expression of $A t D R E B 2 A-C A$ in transgenic cotton plants improved shoot development, morphometrics roots traits as such total volume, length and surface area, beyond deeper roots with greater biomass, contributing to yield advantage under water deficit without displaying any penalty under normal irrigated conditions.

\section{Material and Methods}

\section{Molecular Analysis \\ Cotton transformation}

Embryos of Embrapa 113-7MH cotton cultivar were co-transformed with $25 \mu \mathrm{g}$ of the following DNA fragments: $A H A S$ cassette (obtained by cleavage of pAC321 vector with PvuII restriction enzyme) [44] and pBSK-rd29A::AtDREB2A-CA-NOSt (linearized with $S c a$ I restriction enzyme) [45] (Figure 1(A)). The methodology employed was microparticle bombardment (biolistic) and the resultant transformed plantlets were selected as previously described [46] [47]. The pAC321 vector (8669 bp) contained the AHAS cassette (AtAHAS promoter + AtAHAS coding sequence $+A t A H A S$ terminator) with open reading frame (ORF) mutated at position 653, which resulted in a substitution of a serine by an asparagine that confers herbicide tolerance against the imidazolinone chemical group such as Imazapyr [46]. The pBSK-rd29A::AtDREB2A-CA-NOSt vector (5164 bp) containing the $r d 29 \mathrm{~A}: A t D R E B 2 A-C A$ construction ( $r d 29 \mathrm{~A}$ promoter + AtDREB2A-CA coding sequence + NOS terminator) was kindly provided by JIRCAS (Japan) in collaboration with Embrapa (Brazil). The restriction enzyme $S c a I$ was used to linearize the pBSK-rd29A::AtDREB2A-CA-NOSt vector in order to interrupt the $\beta$-lactamase gene (AmpR).

\section{PCR Analysis}

In the $\mathrm{T}_{0}$ generation, the genomic DNA was extracted from young leaves of transformed and wild-type (WT) cotton plants [48]. In the $\mathrm{T}_{1}$ and $\mathrm{T}_{2}$ generation, the genomic DNA was extracted from seeds [49]. The primers M-Fow and M-Rev (Additional File 2-Table S2) were used to analyze the insertion of AtDREB2A-CA gene in the cotton genome. The PCR mixture consisted of: 300 ng DNA, reaction buffer $(50 \mathrm{mM} \mathrm{KCl} ; 10 \mathrm{mM}$ Tris- $\mathrm{HCl} \mathrm{pH} \mathrm{8.4;0.1 \%} \mathrm{Triton}$ $\mathrm{X}-100) ; 1.5 \mathrm{mM} \mathrm{MgCl}{ }_{2} ; 0.4 \mathrm{mM}$ dNTP; $0.25 \mathrm{mM}$ of each primer and $2.5 \mathrm{U}$ Taq DNA polymerase (Phoneutra ${ }^{\odot}$ ). PCR amplifications were performed at the following conditions: $94^{\circ} \mathrm{C}$ for $5 \mathrm{~min}$; followed by 30 cycles of $94^{\circ} \mathrm{C}$ for $1 \mathrm{~min} ; 55^{\circ} \mathrm{C}$ for $1 \mathrm{~min}, 72^{\circ} \mathrm{C}$ for $1 \mathrm{~min}$; and a last elongation step of $72^{\circ} \mathrm{C}$ for $5 \mathrm{~min}$. The amplicon obtained had $450 \mathrm{bp}$.

Real Time Quantitative PCR ( RT-qPCR) assays

The $A t D R E B 2 A-C A$ transgene expression levels were measured in all plants 


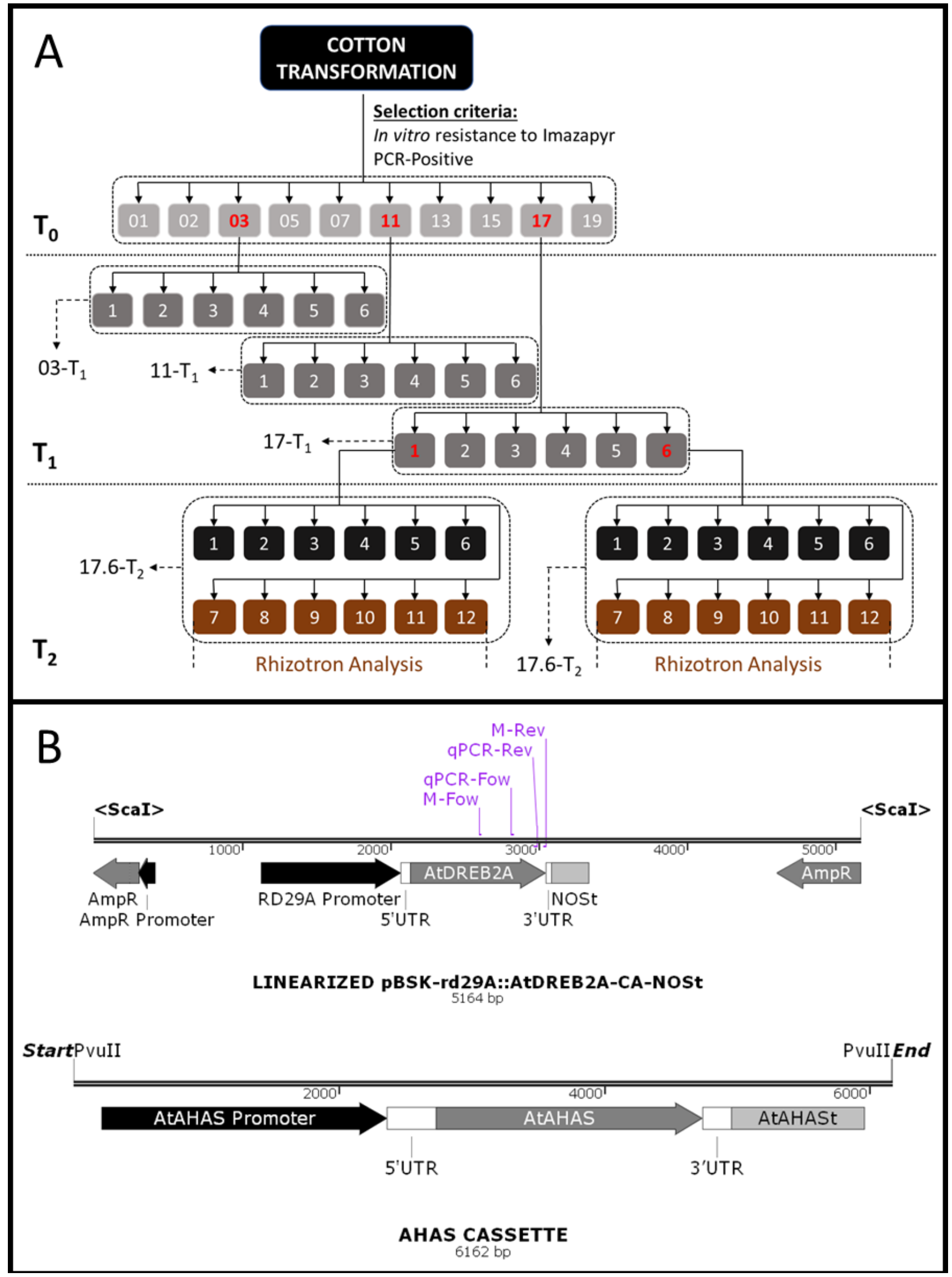




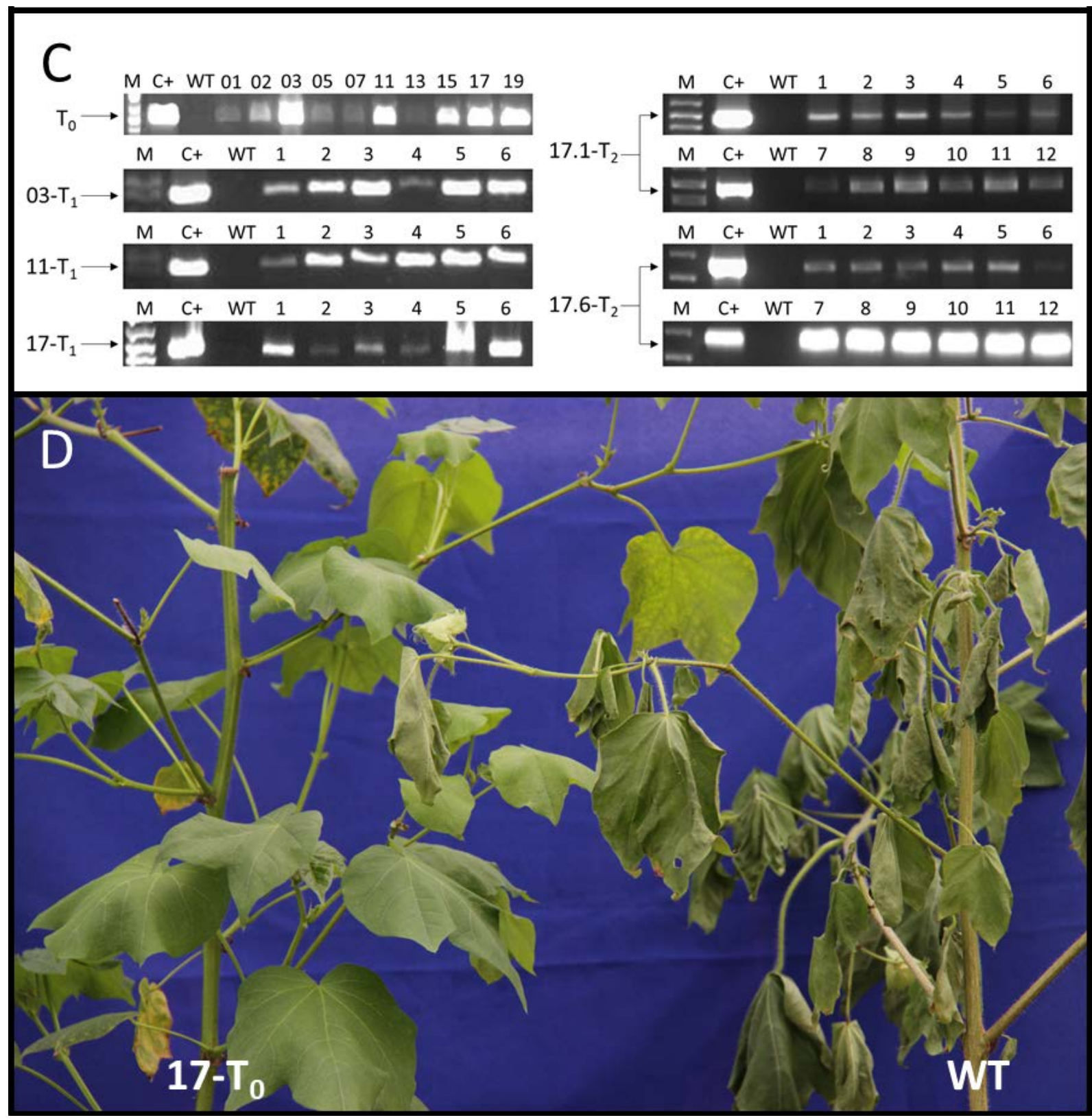

Figure 1. PCR and Phenotypic Selection of $\mathrm{T}_{0} / \mathrm{T}_{1} / \mathrm{T}_{2}$ Cotton Transgenic Plants. The overall experimental design is described in (A). After co-bombard embryos of Embrapa 113-7MH cotton cultivar with linearized pBSK-rd29A::AtDREB2A-CA-NOSt and $A H A S$ cassettes (B), the transformed cotton plants were selected by resistance to Imazapyr conferred by $A H A S$ gene Once acclimated in a greenhouse, the seedlings were characterized by PCR amplification of the AtDREB2A-CA transgene with the M-Fow and M-Rev primers (amplicon with $450 \mathrm{bp}$ ) (C). In this way, ten $\mathrm{T}_{0} \mathrm{PCR}$-positive plants $(01,02,03,05,07,11,13,15,17$ and 19) were selected. These ten $\mathrm{T}_{0}$ cotton plants were phenotypically characterized with regard to drought tolerance. Three of them (03- $\mathrm{T}_{0}, 11-\mathrm{T}_{0}$ and 17- $\left.\mathrm{T}_{0}\right)$ with the healthiest phenotypes when compared to WT after seven days without irrigation were selected, as shown in (D). Six $A t D R E B 2 A-C A$ PCR-positive seeds from the three selected $\mathrm{T}_{0}$ lines were planted and then subjected to physiological analysis. Among the eighteen plants in the $\mathrm{T}_{1}$ generation, the two with the best physiological results were selected (17.1 and 17.6). Finally, twelve $A t D R E B 2 A-C A$ PCR-positive seeds from the $\mathrm{T}_{1}$ selected plants represented the $\mathrm{T}_{2}$ generation (17.1- $\mathrm{T}_{2}$ and 17.6-T $\mathrm{T}_{2}$ ). Legends: PvuII and ScaI (restriction enzyme sites); AmpR (interrupted $\beta$-lactamase open reading frame); AtAHASt (acetohydroxyacid synthase gene terminator); $\mathrm{C}+$ (positive control; $\mathrm{PCR}$ template is the original pBSK-rd29A:: AtDREB2A-CA-NOSt used for cotton transformation); M (1.0 kb ladder; Invitrogen ${ }^{\circledR}$ Cat. \# 10787018); UTR (untranslated region); NOSt (NOS gene terminator); WT (wildtype non-transgenic plants). 
after seven days without irrigation. The total RNA of each leaf replicate (i.e. a leaf disc of $1.0 \mathrm{~cm}$ in diameter) of WT and transgenic cotton plants was isolated using Concert Reagent (Invitrogen ${ }^{\circledR}$ ) following the manufacturer's instructions. All RNA extractions were performed in biological triplicate. Prior to the cDNA synthesis, all of the RNA samples were treated with $1.0 \mathrm{U}$ of Ambion ${ }^{\circledR}$ DNase I RNase-free $^{\text {tm }}\left(\right.$ Invitrogen ${ }^{\circledR}$ ). The cDNA was reverse transcribed from $1.0 \mu \mathrm{g}$ of total RNA using $200 \mathrm{U}$ of Moloney Murine Leukaemia Virus Reverse Transcriptase (M-MLV RT) (Invitrogen ${ }^{\circledR}$ ) and oligo- $\mathrm{NVdT}_{30}$, following the manufacturer's instruction. Informations about the primers used in these experiments (qPCR-Fow and qPCR-Rev for AtDREB2A-CA amplification, as well as GhUBQ14-Fow, GhUBQ14-Rev, GhPP2A1-Fow and GhPP2A1-Rev for amplification of reference controls) are presented in Additional File 2-Table S2. The raw SYBR-fluorescence data from all qPCR amplification runs were imported into the Real-time PCR Miner software [50] to determine the corrected threshold cycle $\left(\mathrm{C}_{\mathrm{t}}\right)$ value and efficiency of the primers. Gene expression analyses were completed using qBASE Plus software [51]. Statistical analysis was performed using REST software (Qiagen ${ }^{\circledR}$ ).

Determination of AtDREB2A-CA transgene expression cassette copy number in the transgenic cotton genome by $q P C R$-based $2^{-\triangle \triangle C t}$

The copy number of $A t D R E 2 A-C A$ transgene in $\mathrm{T}_{0}, \mathrm{~T}_{1}$ and $\mathrm{T}_{2}$ generations of the transgenic cotton plants was determined according to the literature [52] [53] through qPCR-based $2^{-\triangle \Delta C t}$ method. Genomic DNA from WT and $A t D$ $R E B 2 A-C A$ genetically modified (GM) cotton plants was extracted from fresh leaves $\left(100 \mathrm{mg}\right.$ ) using the DNeasy Plant Maxi Kit $\left(\right.$ Qiagen $\left.^{\circledR}\right)$ according to the manufacturer's instructions. The DNA concentration was determined spectrophotometrically and the DNA integrity was checked by agarose gel electrophoresis. A reference plasmid pBSK-AtDREB2A-CA- $u b c 1$ was manufactured containing a fragment of ubiquitin C ( $u b c 1)$ gene from $G$. hirsutum, which is a single-copy gene, as well as a fragment of $A t D R E B 2 A-C A$ gene, which was also present in the AtDREB2A-CA cassette. The copy number of AtDREB2A-CA cassette in the genome of $\mathrm{T}_{0} / \mathrm{T}_{1} / \mathrm{T}_{2} \mathrm{GM}$ cotton plants was calculated from the relative $\mathrm{qPCR}$ quantification of $A t D R E B 2 A-C A$ against the endogenous reference gene $u b c 1$ using the primers qPCR-Fow, qPCR-Rev, GhUBC1-Fow and GhUBC1-Rev (Additional File 2-Table S2). Firstly, the absolute quantity of the two genes $u b c 1$ and $A t D R E B 2 A-C A$ was determined by qPCR in reference to standard curves, which were obtained by plotting the $\mathrm{C}_{\mathrm{t}}$ values against the log-transformed concentration of serial tenfold dilutions $\left(10^{1}, 10^{2}, 10^{3}, 10^{4}\right.$ and $\left.10^{5}\right)$ from the same reference plasmid, pBSK-AtDREB2A-CA-ubcl. Subsequently, the absolute copy number of the plasmid pBSK-AtDREB2A-CA-ubc1 was calculated using $\mathrm{C}_{\mathrm{t}}$ values based on the standard curves. Finally, the relative copy number of the $A t D$ REB2 A-CA target gene was obtained using the ratio between AtDREB2A-CA and $u b c 1$ absolute concentrations in the same sample. 


\section{Phenotypic and Physiological Analysis \\ Water deficit treatment}

Transgenic and WT plants were grown in substrate containing turf and vermiculite $(1: 1 \mathrm{v} / \mathrm{v})$, natural phosphate and macronutrients (Terral, TrueMix). PVC tubes ( $1.2 \mathrm{~m}$ height and $0.35 \mathrm{~m}$ diameter) were filled with $43.0 \mathrm{~kg}$ of substrate previously dried at $105^{\circ} \mathrm{C}$. Subsequently, the tubes were watered from the top until water drained from the bottoms, covered with plastic bags to minimize evaporation, and allowed to drain for $24 \mathrm{~h}$. Then, the drainage holes were sealed and the tubes were weighed for field capacity determination. The assay was carried out under a climatized greenhouse conditions $\left(28^{\circ} \mathrm{C} \pm 2^{\circ} \mathrm{C}\right.$ and $60 \% \pm 10 \%$ relative humidity) and monitored via a Hobo Micro Station Data Logger (Onset Computer). After emergence, $0.5 \mathrm{~L}$ of half-strength Hoagland solution [54] was applied twice a week. The plants were irrigated regularly with water status maintained at the substrate capacity until the first flower occurrence.

A preliminary test was performed to analyze the behavior of transgenic cotton plants under drought conditions. Ten PCR-positives $\mathrm{T}_{0}$ transgenic cotton plants $(01,02,03,05,07,11,13,15,17$ and 19) and non-transformed counterparts were grown in $10 \mathrm{~L}$ plastic pots for 30 days under greenhouse conditions. The $\mathrm{T}_{0}$ transgenic plants were visually assessed for tolerance to water deficit stress by withholding irrigation for seven days and compared with WT. Plants were monitored daily for wilting.

Based in result of preliminary test, those plants that maintained greater visual turgescence were chosen for subsequent evaluations. In the next step, the experiment was performed using a completely randomized design using WT plants and six plants from $\mathrm{T}_{1}$ generation of threeindependent $A t D R E B 2 A-C A$ transgenic cotton events $(03,11$ and 17). Three seeds of each transgenic lines and WT were sown per PVC tube and, after the 12th day, thinning was performed leaving only one plant per PVC tube. Stress treatments were imposed at first flower occurrence and finished after nine days. The evaluation of $\mathrm{T}_{2}$ generation was carried out similarly to the procedures described above. In this phase, based in greatest physiological performance shown before, six transgenic plants from 17.1 and 17.6 $\mathrm{T}_{1}$ transgenic lines were used aiming its morpho-physiological characterization when submitted to water deficit.

\section{Leaf water potential}

At the first flower occurrence, the leaf water potential at predawn (LWPpred-between 4:30 and 5:00 a.m.) was monitored every three days to define the most suitable leaf water status for gas exchange analyses in both transgenic and WT plants [55]. These procedures were conducted using an Oregon Corvallis pressure chamber, 97,330 (PMS Instrument Company) and water potential measurements were performed as described in literature [56]. Briefly, fully expanded cotton leaves were excised with a razor blade near the base of the petiole and immediately inserted into the pressure chamber. Pressure from a tank of compressed nitrogen was applied at the rate of 0.2 to $0.3 \mathrm{bar} \mathrm{sec}^{-1}$ until 
the moment that a drop of exudate appeared on the cut face of the petiole.

\section{Gas exchange measurements}

Gas exchange analysis was also carried out for all trangenic plants $\left(\mathrm{T}_{1}\right.$ and $\left.\mathrm{T}_{2}\right)$ when the WT plant showed approximately $-0.20 \mathrm{MPa}$ (no stress), $-1.20 \mathrm{MPa}$ (moderate stress) and $-1.79 \mathrm{MPa}$ (severe stress) at predawn. Measurements were done using LI-6400 Portable Photosynthesis System (LI-COR, USA). The variables (net photosynthetic rate $-P_{\mathrm{n}}$; stomatal conductance $-g_{\text {s }}$; transpiration rate $-E$ and intercellular carbon concentration $-C_{i}$ ) were measured simultaneously between 9:00 and 11:00 a.m. under artificial photosynthetic photon flux (PPF) $\left(1100 \mu \mathrm{mol} \mathrm{m}^{-2} \mathrm{~s}^{-1}\right)$. The sample chamber was programmed to maintain $400 \mathrm{ppm} \mathrm{CO}_{2}$ at $25^{\circ} \mathrm{C}$ and relative air humidity at $35 \%-50 \%$ for all measurements. The $\mathrm{CO}_{2}$ concentration in the cuvette $(\mathrm{Ca}, \mu \mathrm{bar})$ was controlled using a $12 \mathrm{~g} \mathrm{CO}_{2}$ cartridge in the injector system. Leaves were acclimated in the leaf chamber for two to four minutes until steady-state gas exchange was achieved. For all stressed and control treatments measurements were started on the uppermost fully expanded leaf in the middle third of each plant. The leaves were tagged in order to use the same sample in all measurements and the mid- to distal-portion of each leaf blade was inserted into the LI-6400 chamber.

\section{Shoot and root architecture analysis}

At the end of the stress period, shoots were cut at the cotyledonary node for leaf area (LA) measurements using a portable LA meter (Model LI-3000A) and subsequent shoot dry mass determination in both $\mathrm{T}_{1}$ and $\mathrm{T}_{2}$ generations. For $\mathrm{T}_{1}$ root architecture and morphology analysis, roots were cut and separated from the stems and carefully washed in order to avoid any disturbance to them. The cleaned individual root systems were floated in $5.0 \mathrm{~mm}$ water layer in a $0.5 \times 0.4$ $\mathrm{m}$ Plexiglas tray and untangled with a plastic paintbrush to minimize root overlap.

Additionally, as an alternative for non-destructive root trait measurements of $\mathrm{T}_{2}$ generation, rhizotrons were constructed to analyze, visualize and preserve the root architecture and morphology of WT and $\mathrm{T}_{2}$ transgenic lines (17.1- $\mathrm{T}_{2}$ and 17.6- $\left.\mathrm{T}_{2}\right)$ in order to compare the root trait attributes. Each rhizotron consisted of two transparent glass sheets of $100.0 \mathrm{~cm}$ high, $50.0 \mathrm{~cm}$ wide and $4.0 \mathrm{~mm}$ thick. The two sheets were separated on three sides (two long sides and one of the short sides) by $0.9 \mathrm{~cm}$ aluminum spacers and were held with foldback paper clips. The rhizotrons were filled with $1220 \mathrm{~g}$ of black substrateas described in detail above. Rhizotrons were placed with an inclination of $42^{\circ}$ relatively to vertical position and covered with black plastic sheet to exclude light from the soil and roots, leaving small slits for seedlings to emerge. Before sowing, the rhizotrons were watered to field capacity and the plants were subjected to the same water stress procedures imposing and monitored as previously described.

After stress period, imaging and analysis of root architecture were performed with a camera (Sony Cyber Shot DSC-HX1, Optical Zoom 20X) and the photographed images were analyzed with WinRHIZO PRO to determine total root 
length, surface area and volume.

Osmotic adjustment analysis

The youngest fully developed leaves from $17.1-\mathrm{T}_{2}$ and 17.6- $\mathrm{T}_{2}$ transgenic cotton lines were rehydrated for $12 \mathrm{~h}$ and sampled according to LWP pred thresholds values defined above. Then, each leaf was washed with deionized water, sealed in a $20.0 \mathrm{~mL}$ plastic syringe, immediately frozen in liquid nitrogen and stored at $-20^{\circ} \mathrm{C}$ until required. For osmolality analysis, syringes containing leaf samples were manually pressurized and the sap was transferred to a $1.5 \mathrm{~mL}$ plastic microtube for subsequent centrifugation $\left(10,000 \mathrm{~g}\right.$ for $10 \mathrm{~min}$ at $\left.0^{\circ} \mathrm{C}-4^{\circ} \mathrm{C}\right)$. Sap samples were taken for osmolality determinations using a Vapor Pressure Osmometer (Vapro 5600, Wescor Biomedical Systems Inc.). The osmotic potential was determined using the ideal gas equation ( $\psi \mathrm{s}=-\mathrm{RTcs})$, where $R$ is the gas constant $\left(8.32 \mathrm{~J} \mathrm{~mol}^{-1} \mathrm{~K}^{-1}\right), \mathrm{T}$ is the absolute temperature (in Kelvin degrees) and $c s$ is the solute concentration in the solution, expressed as osmolality. Osmotic adjustment was calculated by the rehydration method [57], which was calculated by the difference between osmotic potential measured in non-stressed and stressed leaves after full rehydration.

\section{Effect of water deficit on yield}

The productivity of transgenic cotton progenies was estimated as the mean number of reproductive structures, including squares (flower bud stage before blooming), flowers (perfect flowers) and bolls (fruits)retained in the $\mathrm{WT}$ and $\mathrm{T}_{2}$ transgenic lines (17.1- $\mathrm{T}_{2}$ and 17.6- $\left.\mathrm{T}_{2}\right)$ seven days after re-watering establishment.

\section{Statistical analyses}

Data were subjected to analysis of variance (ANOVA, $p<0.05$ ) and comparison of means was performed with Student's $t$-test $(p<0.05)$ using SPSS Statistics software. The physiological parameters obtained for the transgenic lines were compared with those of WT plants for each water regime.

\section{Results}

\section{Plant Transformation and Molecular Analysis}

The overall experimental design was in accordance with the flowchart in Fig. 1A.Two different vectors, one containing the AtDREB2A-CA gene and the other containing the $A H A S$ gene (selective marker that confers resistance to Imazapyr) were used to co-bombard apical meristems of mature cotton embryos of Embrapa 113-7MH cultivar (Figure 1(B)). From 3000 embryos bombarded, 148 (4.93\%) putative AHAS-transformed plantlets were selected by resistance to Imazapyr. Genomic DNA was extracted from leaves of the surviving transgenic plants and was used for PCR analysis to verify the presence of AtDREB2A-CA. Thus, ten $\mathrm{T}_{0} \mathrm{PCR}$-positive independent transgenic events were identified (Figure $1(C)$ ), which indicated a transformation frequency of $0.33 \%$. Three $\mathrm{T}_{0}$ primary transformed plants $\left(03-\mathrm{T}_{0}, 11-\mathrm{T}_{0}\right.$ and $\left.17-\mathrm{T}_{0}\right)$ were selected on the basis of a drought tolerance phenotype after seven days without irrigation, as shown in 
Figure 1(D). After this period, WT plants became totally withered while the selected $\mathrm{T}_{0}$ transgenic plants were erect with turgid leaves. Then, the three selected $\mathrm{T}_{0}$ generation plant were self-pollinated and the seeds were used to obtain the $\mathrm{T}_{1}$ progeny. Six AtDREB2A-CAPCR-positive plants from $\mathrm{T}_{1}$ generation of each selected primary transformation event were phenotipically and physiologically evaluated. After detailed physiological analysis (results described below), twelve PCR-positive seeds of the two $\mathrm{T}_{1}$ trangenic plant with the best results $\left(17.1-\mathrm{T}_{1}\right.$ and 17.6- $\mathrm{T}_{1}$ ) were sown for $\mathrm{T}_{2}$ generation analysis. Six PCR-positive seeds of each selected $T_{2}$ transgenic line (plants 7-12 of both 17.1- $T_{2}$ and 17.6- $T_{2}$; Figure $1(C)$ ) were used for rhizotron analysis.

The expression profile of the AtDREB2A-CA transgene in the selected transgenic lines was evaluated after seven days without irrigation (Figure 2). The $17-\mathrm{T}_{0}$ transgenic plant presented the highest level of transgene expression in this condition, followed by its $T_{1}$ and $T_{2}$ progeny. In addition, $17-T_{0}$ carried in its

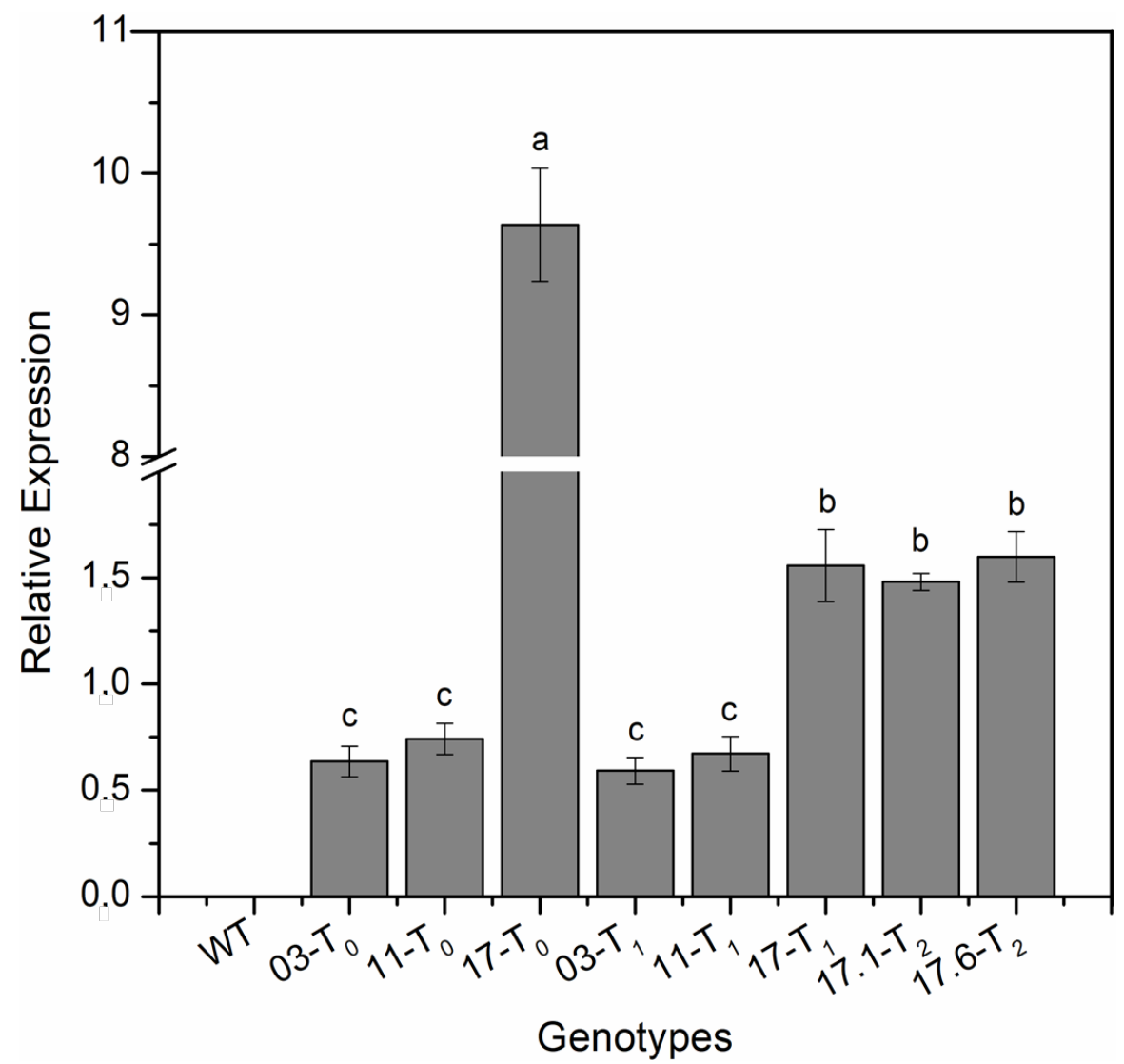

Figure 2. Relative Expression of AtDREB2A-CA Transcript. The expression of the AtD$R E B 2 A-C A$ transgene was measured in transgenic and WT plants after seven days without irrigation with qPCR-Fow and qPCR-Rev primers. Each bar represents the transcript expression level of three technical and biological replicates of the six $\mathrm{T}_{1}\left(03-\mathrm{T}_{1}, 11-\mathrm{T}_{1}\right.$, and 17- $\left.\mathrm{T}_{1}\right)$ and twelve $\mathrm{T}_{2}\left(17.1-\mathrm{T}_{2}\right.$ and 17.6- $\left.\mathrm{T}_{2}\right)$ PCR-positive selected transgenic plants \pm standard error.Statistical analysis was performed according to the Student's $t$-test $(p<$ $0.05)$. Identical letters above the bars indicate that the means were not significantly different. Legends: WT (wildtype non-transgenic plants). 
genome two copies of the transformation cassette containing the AtDREB2A-CA transgene, while all the other selected transgenic plants had only one copy (Table 1). These combined results indicate transgene stabilization in the transformed plants, especially in the $\mathrm{T}_{2}$ generation.

\section{Physiological Analysis \\ Leaf water potential and gas exchange analysis}

At the beginning of water with drawal, the LWP pred of $T_{1}$ and $T_{2}$ plants was always kept at $-0.5 \mathrm{MPa}$ or greater (less negative) (Figure 3(A) and Figure 3(B),

Table 1. Copy number of the AtDREB2A-CA DNA cassette in GM cotton plants.

\begin{tabular}{ccc}
\hline Plant ID & AtDREB2 $A-C A / U B C$ ratio & Estimated copy number \\
\hline WT & -0.34 & 0 \\
$03-\mathrm{T}_{0}$ & 1.27 & 1 \\
$11-\mathrm{T}_{0}$ & 1.26 & 1 \\
$17-\mathrm{T}_{0}$ & 2.35 & 2 \\
$\mathbf{0 3} \mathrm{T}_{1}{ }^{*}$ & $1.22-1.39$ & 1 \\
$11-\mathrm{T}_{1}{ }^{*}$ & $1.13-1.28$ & 1 \\
$17-\mathrm{T}_{1}{ }^{*}$ & $1.14-1.24$ & 1 \\
$17.1-\mathrm{T}_{2}{ }^{* *}$ & $1.17-1.21$ & 1 \\
$17.6-\mathrm{T}_{2}{ }^{* *}$ & $1.19-1.30$ & 1 \\
\hline
\end{tabular}

*The number of copies was evaluated in all the six $\mathrm{T}_{1}$ plants of each analyzed transgenic line $(03,11$ and 17). The AtDREB2A-CA/UBC ratio presented is the range of values found in the analysis of the six plants. ${ }^{*}$ The number of copies was evaluated in all twelve $\mathrm{T}_{2}$ plants of each analyzed transgenic line (17.1 and 17.6). The AtDREB2A-CA/UBC ratio presented is the range of values found in the analysis of the twelve plants.
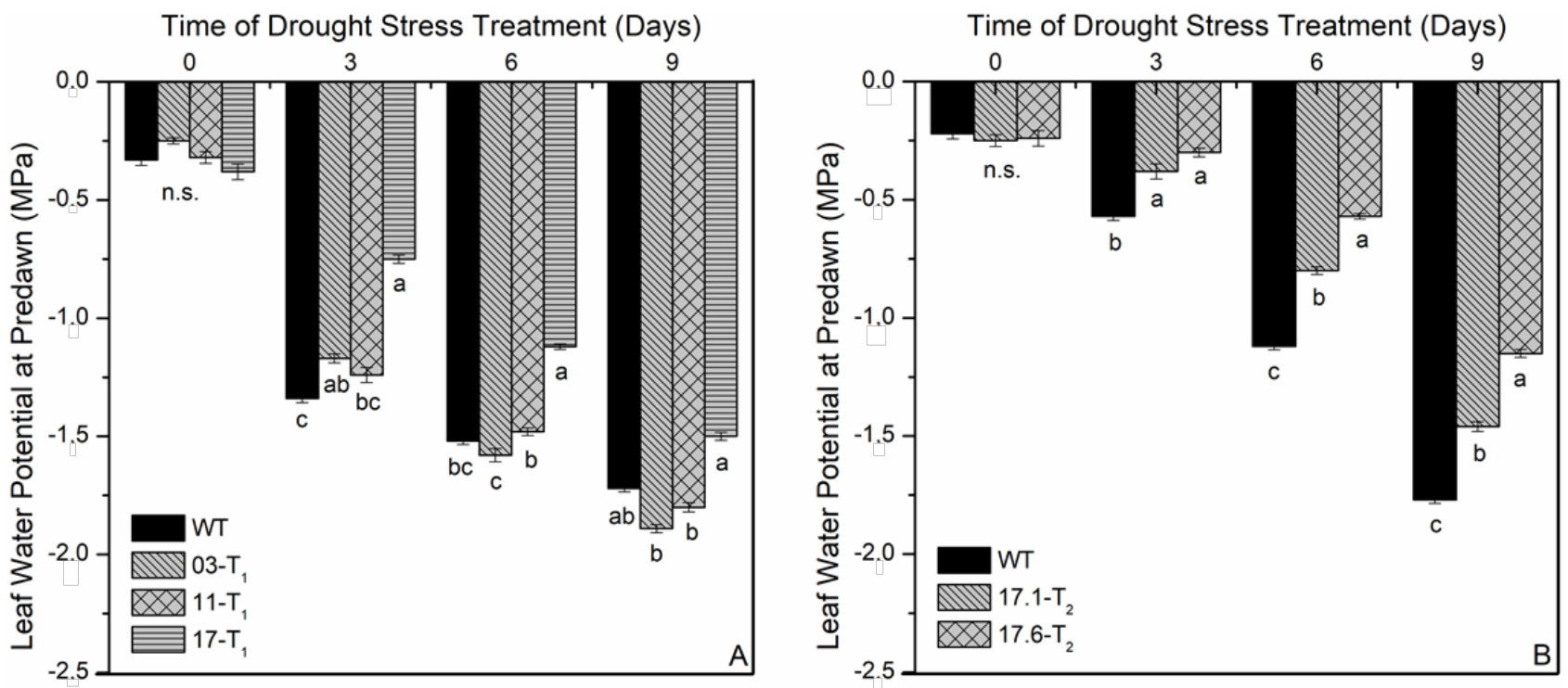

Figure 3. Leaf Water Potential at Predawn in $\mathrm{T}_{1} / \mathrm{T}_{2}$ Transgenic Cotton Plants at Flowering. (A) $\mathrm{T}_{1}$ generation $\left(03-\mathrm{T}_{1}, 11-\mathrm{T}_{1}\right.$ and 17- $\left.\mathrm{T}_{1}\right)$; (B) $\mathrm{T}_{2}$ generation (17.1- $\mathrm{T}_{2}$ and 17.6- $\mathrm{T}_{2}$ ). All measurements were recorded at three, six and nine days after imposing water stress. Each bar represents the mean of six replicates \pm standard error. Statistical analysis was performed according to Student's t-test $(p<0.05)$. Identical letters above the bars indicate that the means were not significantly different. Legends: WT (wild type non-transgenic plants); n.s. (non-significant). 
respectively). As shown in the $\mathrm{T}_{1}$ cotton plants, after nine days without irrigation, WT plants and descendants from the transgenic line 17 reached -1.72 and -1.50 MPa LWPpred, respectively. The 17.1- $\mathrm{T}_{2}$ and 17.6- $\mathrm{T}_{2}$ transgenic lines reached on average -1.46 and $-1.15 \mathrm{MPa}$, respectively, at predawn during the same stress period, while the LWPpred of the WT plants was $-1.77 \mathrm{MPa}$.

In respect to LWPpred thresholds for gas exchange analysis, the leaf water status was allowed to progress until approximately -1.20 (moderate stress) and $-1.79 \mathrm{MPa}$ (severe stress) in WT plants, considering their more accelerated LWPpred decline compared to the transgenic lines, as observed in preview tests with cotton leaf and whole canopy photosynthesis [55] [58].

Increased water deficit leaded to greater gas exchange performance in transgenic plants when compared with WT plants for both $\mathrm{T}_{1}$ and $\mathrm{T}_{2}$ generations (Figure 4$). P_{\mathrm{n}}$ values decreased for all genotypes as the stress imposing progressed (Figure 4(A1) and Figure 4(A2)). However, in general, the results in the $T_{2}$ progeny from 17 transgenic line were significantly different from those in WT plants at moderate $(-1.20 \mathrm{MPa})$ and severe $(-1.79 \mathrm{MPa})$ stress level, which indicated that cotton lines over expressing AtDREB2A-CA improved their net photosynthetic rate even when maintained under water deficit regime. Stomatal conductance $\left(g_{s}\right)$ values were greatly influenced by stress, but descendants from 17 transgenic line showed the highest values for this variable in comparison with other genotypes under the most stressful condition (Figure 4(B1) and Figure 4(B2)). The same trend was registered for $E$ (Figure $4(\mathrm{C} 1)$ and Figure $4(\mathrm{C} 2)$ ) and $C_{i}$ (Figure 4(D1) and Figure 4(D2)), highlighting the 17 transgenic line outperformance. As water deficit treatment progressed, the proportional decrease in the $P_{n}$ was significantly less affected than the decrease in stomatal conductance, demonstrating the different roles of stomatal responses on the gas exchange parameters in the analyzed lines. Data from the $\mathrm{T}_{2}$ generation demonstrated that the most evidenced differences between the transgenic lines and WT plants were observed at severe stress level for all gas exchange variables analyzed. There was a strong $g s$ decrease in WT plants when compared with the transgenic lines. This trend also extended for the $E$ and $C i$ parameters. On the other hand, $P_{\mathrm{n}}$ performance was less affected in terms of magnitude across stress levels, with reduced values for WT plants varying from $25.81 \%$ (moderate stress) to $56.63 \%$ (severe stress) in comparison with well-watered conditions. On the other hand, the 17.1- $\mathrm{T}_{2}$ transgenic line showed a slow progress and a small final proportional decrease in $P_{n}$, varying from $21.64 \%$ to $28.47 \%$ in both described stress levels.

\section{Shoot morphology and root traits}

Analysis of growth variables on WT and transgenic lines under the most severe stress condition is shown in Figure 5. Significant differences were observed in plant height (Figure 5(A)), dry mass (Figure 5(B)) and LA (Figure 5(C)) among 17 progeny and WT plants, indicating that this transgenic line showed a similar (sometimes even better) growth pattern under drought stress conditions, 



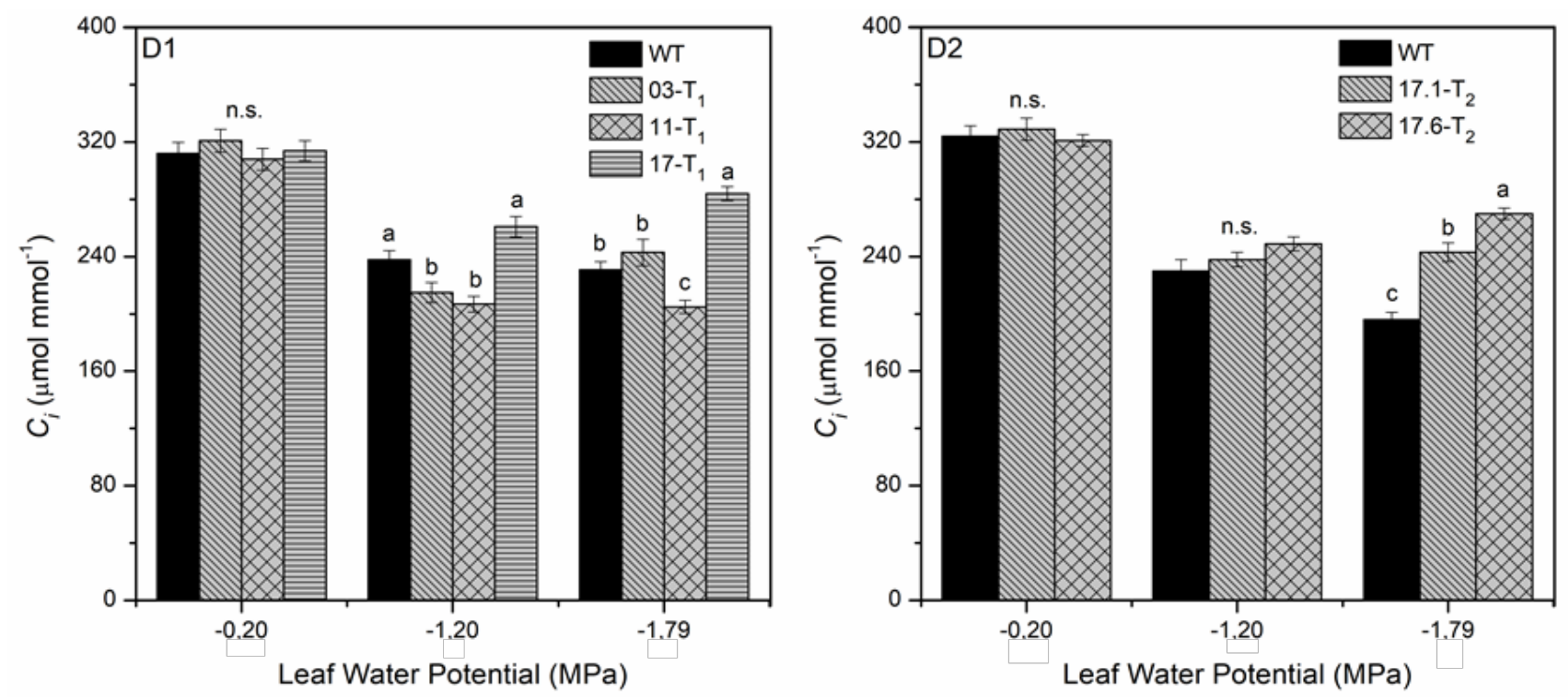

Figure 4. Gas Exchange Measurements in $\mathrm{T}_{1} / \mathrm{T}_{2} r d 29 \mathrm{~A}:$ :AtDREB2 A-CA Cotton Plants. (A) net photosynthetic rate- $P_{\mathrm{n}}$; (B) stomatal conductance $-g_{s} ;(\mathrm{C})$ transpiration rate $-E$ and $(\mathrm{D})$ intercellular carbon concentration $-\mathrm{C}_{\mathrm{i}}$ monitored in WT plants and transgenic lines exposed to drought stress. Column (1) $\mathrm{T}_{1}$ generation (03- $\mathrm{T}_{1}, 11-\mathrm{T}_{1}$ and 17- $\left.\mathrm{T}_{1}\right)$; Column (2) $\mathrm{T}_{2}$ generation (17.1- $\mathrm{T}_{2}$ and 17.6- $\mathrm{T}_{2}$ ). Drought stress treatment was applied according to leaf water status: $-0.20 \mathrm{MPa}$ (no stress), $-1.20 \mathrm{MPa}$ (moderate stress) and $-1.79 \mathrm{MPa}$ (severe stress) at predawn. Each bar represents the average of six replicates \pm standard error. Statistical analysis was performed according to the Student's $t$-test $(p<0.05)$. Identical letters above the bars indicate that the means were not significantly different. Legends: WT (wildtype non-transgenic plants); n.s. (non-significant).

when compared with WT plants. In addition, the imaging analysis of the root system showed that the $17-\mathrm{T}_{2}$ progeny rooted into deeper soil layers than the other genotypes (Figures 5(D)-(F)). The total root volume, length and surface area of this transgenic line were more than 2-fold higher than WT plants and significantly superior to other transgenic lines. The rhizotron assay confirmed this root pattern, showing that the $17-\mathrm{T}_{2}$ transgenic roots were longer than WT one (Figures 5(G1)-(G3)).

\section{Osmotic adjustment}

A markedly contrasting response for osmotic adjustment was observed when comparing the $\mathrm{T}_{2}$ transgenic lines $17.1-\mathrm{T}_{2}(0.63 \mathrm{MPa})$ and 17.6- $\mathrm{T}_{2}(0.45 \mathrm{MPa})$ with WT plants $(0.90 \mathrm{MPa})$ at the most severe drought stress level (Figure 6). These results suggested that possibly the favourable morpho-physiological traits shown by transgenic lines (deeper and denser root system) allowed them to reduce the metabolic costs involved in osmotic adjustment response and in other antioxidant pathways activation.

\section{Yield components}

For cotton crop grown under real field conditions, the number of reproductive structures retained per plant, specially squares (flower bud stage before blooming), flowers (perfect flowers) and young bolls (fruits less than two centimeter in diameter) is the most important yield component, which can influence cotton productivity. Even though the experiments were carried out under controlled conditions (greenhouse), drought stress consistently led to noticeable 

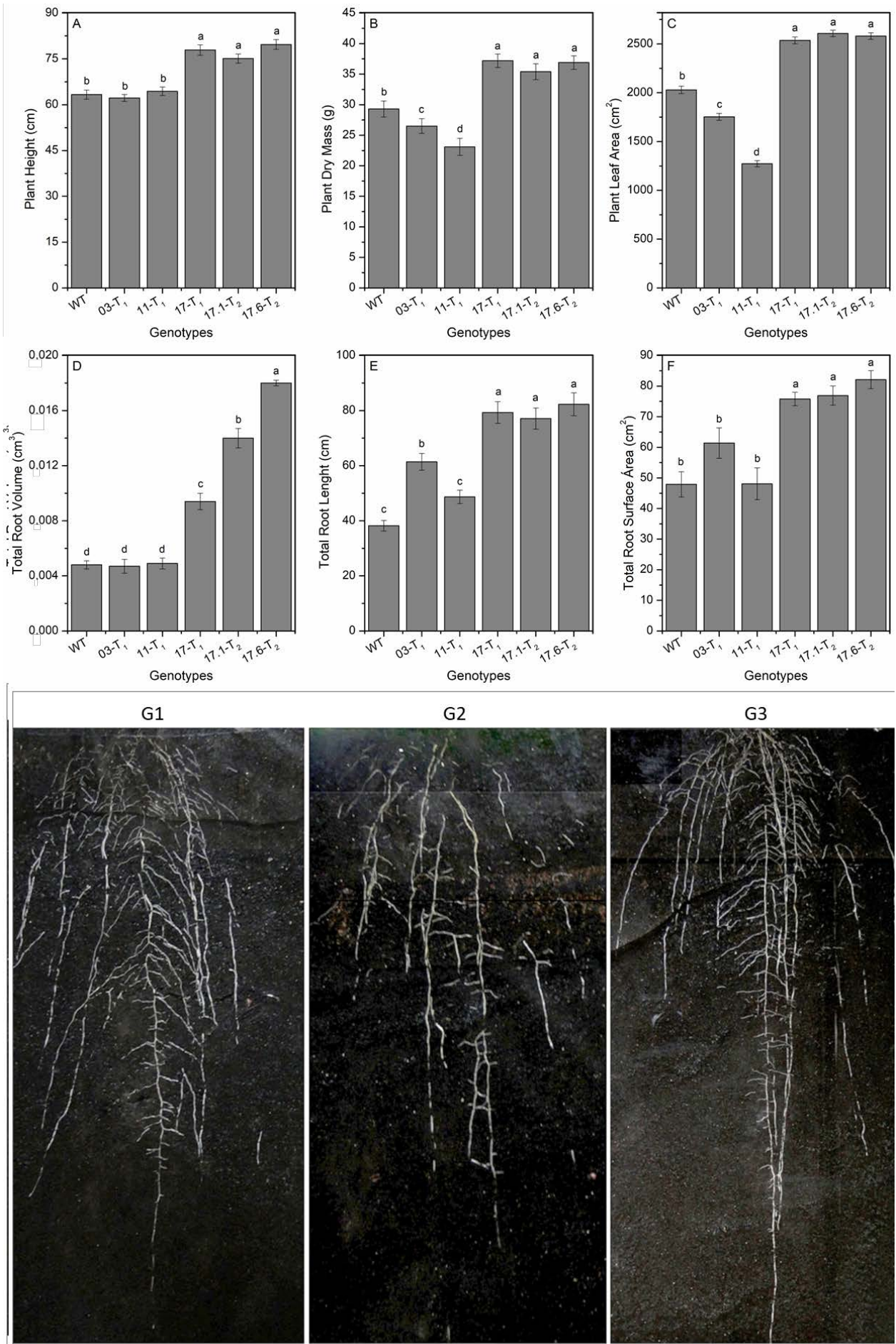

G2

G3
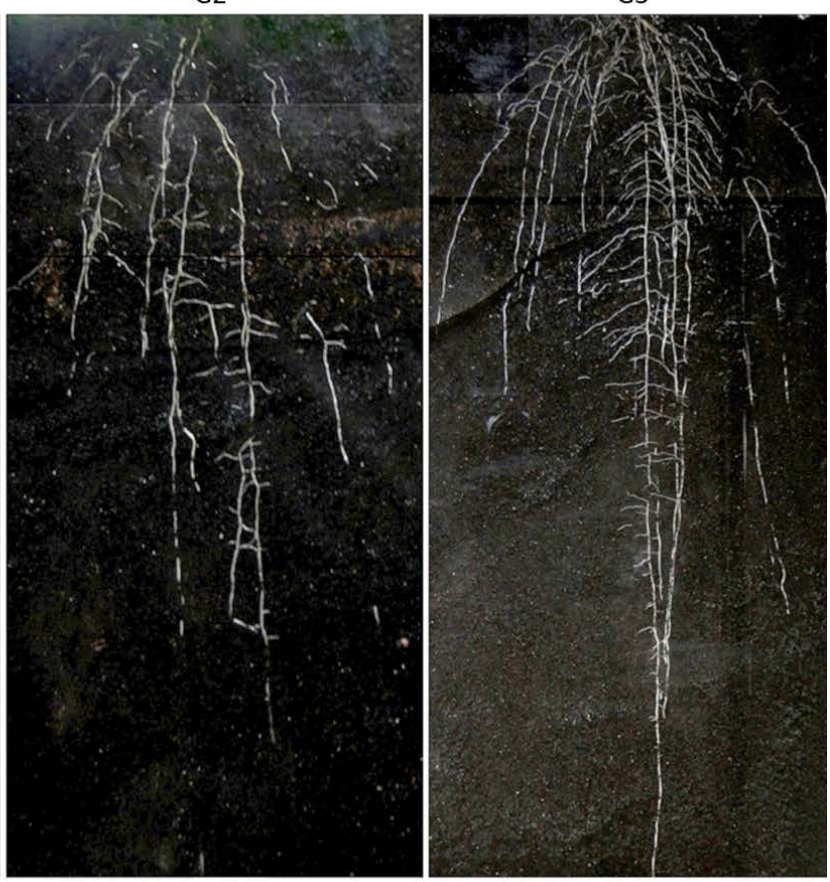

17.1- $\mathrm{T}_{2}$

WT

17.6- $\mathrm{T}_{2}$

Figure 5. Evaluation of Shoot and Root Morphology of the $\mathrm{T}_{1} / \mathrm{T}_{2} r d 29 \mathrm{~A}:: A t D R E B 2 A-C A$ Cotton Plants. Shoot traits ((A)-(C)) and root architecture ((D)-(F)) quantified in WT plants and transgenic lines exposed to severe drought stress (leaf water status of $-1.79 \mathrm{MPa}$ at predawn). Main features of the $17-\mathrm{T}_{2}$ roots in rhizotron analysis: (G1) 17.1- $\mathrm{T}_{2}$; (G2) WT; and (G3) 17.6- $\mathrm{T}_{2}$. AtD$R E B 2 A-C A$ cotton plants displayed deeper root when compared with WT plants at LWPpred at $-1.79 \mathrm{MPa}$, approximately. Each bar represents average of six replicates \pm standard error. Statistical analysis was performed according to the Student's $t$-test $(p<$ 0.05). Identical letters above the bars indicate that the means were not significantly different. Legends: WT (wildtype non-transgenic plants). 




Figure 6. Osmotic Adjustment of $\mathrm{T}_{2} r d 29 \mathrm{~A}:$ :AtDREB2 A-CA Cotton Plants. Osmoregulation was analyzed in WT plants and $\mathrm{T}_{2}$ transgenic lines $\left(17.1-\mathrm{T}_{2}\right.$ and 17.6- $\left.\mathrm{T}_{2}\right)$. Drought treatment was applied according to leaf water status: $-1.20 \mathrm{MPa}$ (moderate stress) and $-1.79 \mathrm{MPa}$ (severe stress) at predawn. Each bar represents the average of six replicates \pm standard error. Statistical analysis was performed according to the Student's $t$-test ( $p<$ 0.05 ). Identical letters above the bars indicate that the means were not significantly different. Legends: WT (wildtype non-transgenic plants).

differences between the 17.6- $\mathrm{T}_{2}$ transgenic line and WT plants in the number of retained reproductive structures (Figure 7) per plant, which was approximately $26.0 \%$ higher in the transgenic line under severe water shortage conditions.

\section{Discussion}

The present investigation provides the first report of a GM cotton plant tolerant to drought stress due to the presence of the AtDREB2A-CA gene driven by the $r d 29 \mathrm{~A}$ inducible promoter, instead of the CaMV $35 \mathrm{~S}$ constitutive promoter. Employing an optimized biolistic transformation protocol [47], a high transformation frequency was obtained with the cotton cultivar Embrapa 113-7MH.

The particle bombardment process often results in complex transgene integration patterns [59] [60]. In contrast to this statement, the present study showed that just one or two copies of AtDREB2A-CA cassette were integrated into the cotton genome. Low number of transgene copies was also observed in a previous study of transgenic cotton plants transformed by a biolistic procedure [53]. Molecular analysis confirmed the successful integration of the transgene in the $\mathrm{T}_{0}$ plants, as well as in the subsequent generations $\left(\mathrm{T}_{1}\right.$ and $\left.\mathrm{T}_{2}\right)$.

The use of the $r d 29$ A promoter allowed cotton plants to preserve their physiological functions and did not affect any other relevant feature. Similarly, in 




Figure 7. Effect of Drought on Yield Components of $\mathrm{T}_{2} r d 29 \mathrm{~A}:: A t D R E B 2 A-C A$ Cotton Plants. The number of reproductive structures (squares, flowers and boll fruits) retained per plant was evaluated in WT plants and $\mathrm{T}_{2}$ transgenic lines $\left(17.1-\mathrm{T}_{2}\right.$ and $\left.17.6-\mathrm{T}_{2}\right)$ seven days after re-irrigation establishment. Each bar represents the average of six replicates \pm standard error. Statistical analysis was performed according to the Student's $t$-test ( $p<$ 0.05).Identical letters above the bars indicate that the means were not significantly different. Legends: WT (wildtype non-transgenic plants).

other studies, the over expression of DREB genes under the control of the $r d 29 \mathrm{~A}$ promoter conferred increased drought and freezing tolerance into transgenic Arabidopsis, tobacco, wheat, peanut, groundnut and rice plants without growth retardation [16] [24] [61] [62] [63] [64]. Conversely, the use of CaMV 35S promoter has led to growth and yield penalties in a variety of $D R E B$-transgenic plants [18] [61] [65]. Only few exceptions showed few or no changes in the phenotypes of transgenic plants the $D R E B$ constitutively over expressing $D R E B$ genes [66] [67] [68]. Another important feature of the $r d 29 \mathrm{~A}$ promoter is that it can be induced in all plant organs including leaves and roots, working as a component of stress perception and signaling in response to water deficits [69]. Qualitative and quantitative assays in soybeans cultivars with the $r d 29 \mathrm{~A}:: G U S$ cassette showed significant $r d 29 \mathrm{~A}$ promoter activity in soybean plants subjected to dry-down conditions. In addition, the reporter gene expression was notably higher in roots than in leaves and the $r d 29 \mathrm{~A}$ promoter did not result in agronomic penalties through leaky expression when no abiotic stress was imposed [70].

Currently, only a few $D R E B$-related genes have been introduced into different 
cultivars aiming to improve water deficit tolerance around the world (Additional File 3: Table S3) [14] [18] [45] [71] [72] [73] [74]. Several studies have been performed in order to establish parameters to assess GM drought-tolerant cotton plants (Additional File 4: Table S4) [27]-[36]. The employment of physiological and agronomic traits has been able to distinguish tolerant and sensitive genotypes to dehydration [58] [62]. Water deficit perception occurs later in GM drought-tolerant plants compared with WT plants, i.e., wilting, reduced stomatal conductance, transpiration and photosynthesis [12]. In the present study, under well-watered conditions, the genotypes displayed similar physiological behaviors for most parameters, which indicate that the insertion of $A t D R E B 2 A-C A$ did not negatively affect their performance. The same observation was previously reported for $r d 29 \mathrm{~A}:: D R E B 1 A$-peanut plants under normal irrigated conditions [62].

In this report, all the gas exchange variables were higher among the descendants from 17 transgenic cotton line, when compared with WT plants as drought intensity progressed from $-1.20 \mathrm{MPa}$ (moderate stress) to $-1.79 \mathrm{MPa}$ (severe stress). This observation reflected the greater ability of the transgenic plants to acquire a larger amount of water as a consequence of its deeper and greater-biomass roots. These results suggest that this transgenic line could tolerate a suboptimal water supply, most likely due to the situational activation of the stress-responsive $A t D R E B 2 A-C A$ gene driven by the $r d 29 \mathrm{~A}$ promoter. The stress induced expression of $r d 29 \mathrm{~A}:: D R E B 1 A$ in transgenic peanut plants demonstrated that it caused no morphological alterations in comparison with WT control plants, which may be attributed to stress-inducible expression of the transgene [62]. In contrast, other studies have shown that both non-transformed and $r d 29 \mathrm{~A}:: S b D R E B 2$-rice plants subjected to drought conditions showed leaf rolling symptoms, which indicated that the water regulation mechanisms were similar in transgenic and WT plants [63]. Enhanced drought tolerance in transgenic wheat and barley transformed with 2x35S-TaDREB2 and 2x35S-TaDREB3 resulted in slower growth, delayed flowering and lower grain yields than control plants under water deficit conditions, most likely due to the pleiotropic promoter effect [61].

Compared with the $T_{1}$ and $T_{2}$ descendants from 17 line, the other transgenic cotton lines $\left(03-\mathrm{T}_{1}\right.$ and $\left.11-\mathrm{T}_{1}\right)$ showed restricted water loss, as evidenced by their similar or inferior stomatal conductance and transpiration rate performance compared with WT plants, indicating a conflict between water conservation and net $\mathrm{CO}_{2}$ assimilation in these plants. Moreover, the same plants showed similar or lower values for plant height, dry mass, LA, root volume, root length and root surface area when compared with WT plants at the end of stress period. Among several possibilities, the transgene stability could be one reason that explains the differences observed in each transformation event. The position effect, which reflects the influence of genomic DNA surrounding the transgene introduction site, as well as locus structure, which influences the likelihood of physical inte- 
ractions and further recombination within the locus, can determine effective transgene stability and plant metabolic rearrangement, culminating in the expected phenotype for GM plants [75] [76]. Studies show that the extent of the differences between the phenotypes of transgenic and control plants may also be explained by variation in the number and type of target genes induced by DREB transgene over expression in certain plant species [23].

The maximum cotton rooting depth and density may help plants to maintain their water status at a relatively higher level due to an increased capacity to exploit water in the soil deeper layers [58] [77]. The root data shown in this study clearly indicated that the AtDREB2A-CA gene conferred an advantage on the descendants from 17 transgenic line under drought stress conditions, by improving total root length, volume and surface area. This response would be beneficial if these transgenic cotton plants were grown in the field, where they could access water in the deeper soil layers via their root architecture traits and robustness. Under some unstable climatic conditions, better root architecture helps plants to avoid water deficit and consequently reduces the metabolic cost of the osmotic adjustment pathway, decreasing the negative impact on gas exchange performance and its yield components. Thus, the expression of these traits allows plants to maintain greater stomatal conductance and higher $\mathrm{CO}_{2}$ rate diffusion, increasing the net photosynthesis, growth and yield. Studies have shown that water stress treatment promoted better root growth in $r d 29 \mathrm{~A}$ :: $D R E B 1 A$ transgenic peanut lines in comparison with WT plants and that this was partially related to the stimulation of root penetration into deeper soil layers [78]. In contrast, sugarcane plants transformed with AtDREB2A-CA did not show significant differences in root diameter, volume or length [73]. As reported in other study, roots may explore a larger volume of soil to obtain more water, however, this important parameter is rarely considered during GM analysis [12].

Since the $17-\mathrm{T}_{1}$ transgenic plants (manly 17.1 and 17.6) showed better morphophysiological results, their progenies were selected for further studies in $\mathrm{T}_{2}$ generation to confirm the effects of transgene expression. Both $T_{1}$ and $T_{2}$ generations exhibited similar physiological performance during severe stress, which is in agreement with the proposed function of $r d 29 \mathrm{~A}:: A t D R E B 2 A-C A$. During the most severe stress, the $\mathrm{T}_{2}$ transgenic lines, especially the 17.6- $\mathrm{T}_{2}$, maintained a higher LWPpre (-1.15 MPa) than WT plants $(-1.67 \mathrm{MPa})$, which was coupled with improved gas exchange performance. Mechanisms of delayed drought perception can result from decreased water loss (stomatal closure, reduced LA and senescence of old leaves) or increased water absorption (deeper root systems) [79] [80] [81]. The enhanced physiological (photosynthetic indexes) and rooting depth traits observed in the $17-\mathrm{T}_{1}$ descendants contributed to better morphological and yield performance.

The deeper rooting depth and density shown by the 17.1- $\mathrm{T}_{2}$ and $17.6-\mathrm{T}_{2}$ transgenic lines allowed them to maintain greater cell turgor and consequently lower the demand on activating osmotic adjustment pathways, when compared 
with non-transgenic plants. The key role of osmotic adjustment is cell-turgor preservation during water deficit conditions, which is essential for the maintenance of turgor-related processes, especially stomatal regulation [82] [83] [84]. Osmotic adjustment is considered a crucial process for plant adaptation to drought because it sustains tissue metabolic activity and enables regrowth upon re-watering, although it varies greatly among genotypes [85]. Nevertheless, osmotic adjustment is important for root traits, enabling their sustained growth under decreasing water availability in soil [86].

The expression of $A t D R E B 2 A-C A$ in cotton plants also significantly improved drought tolerance during the reproductive stage. The transgenic lines had substantially improved retention of reproductive structures (squares, flowers and bolls), approximately $26.0 \%$ higher than that of WT plants. Although yield components were not evaluated under non-stressed conditions, we assume that they would not be lower, once AtDREB2A-CA insertion did not cause any morphophysiological penalty to the plants in non-stressed conditions. In this report, it was evident that the modifications in the root architecture of transgenic lines were correlated with physiological attributes and yield components. For cotton breeding, strategies using stomatal conductance regulation, osmotic adjustment capability and promotion of a larger and deeper root are pursued to favour better water status and fiber yield when plants are subjected to water deficiency [58] [77]. The performance of cotton lines over expressing stress responsive NAC1 (SNAC1) under drought and salt stress conditions was significantly better than WT plants in terms of boll number [36]. Similarly, cotton transgenic lines transformed with GHSP26 (Heat Shock Protein Gene), GUSP1 (Universal Stress Protein Gene) and Phyto-B (Phytochrome-B Gene) showed a significant increase in the number of bolls per plant, single boll weight, and seed cotton yield under drought stress, when compared with WT plants [34]. An improvement of yield components up to $24.0 \%$ in drought trials under field conditions was achieved using $D R E B 1 A$-peanut plants across a wide range of stress intensities and resulted in higher harvest indices [62]. Thus, our study highlighted that, despite being a proof of concept, the increase in production observed in the $T_{2}$ descendants from 17 transgenic lines can be considered a promising result in obtaining transgenic cotton more tolerant to drought.

\section{Conclusions}

Based on our findings, the 17-AtDRE2A-CA-cotton line exhibited enhanced drought tolerance in comparison with control plants via a more robust root system trait. The high and stable physiological features followed by better gas exchange indexes displayed by this line were also maintained among its descendants ( $T_{2}$ generation). The superior rooting depth and density of this transgenic line resulted in higher ability to acquire water in deeper layers, which likely contributed to its higher yield components in drought conditions, when compared to its WT counterpart. Moreover, this high performance was confirmed by im- 
proved photosynthetic data, leading to higher numbers of retained reproductive structures in these plants. To the best of our knowledge, the present work is the first report in cotton demonstrating a physiological and yield advantage attributes under drought stress using the AtDREB2A-CA transcription factor. Further evaluation will be performed under field conditions in order to assess whether $A t D R E B 2 A-C A$ gene can be used to increase cotton crop production in water-limited real field trials.

\section{Acknowledgements}

The present work was supported by grants of funds from the Brazilian government (EMBRAPA, CNPq, CAPES and FAPDF). We thank the Japan International Research Center for Agricultural Sciences (JIRCAS) for supplying the AtDREB2A-CA vector cassette according to the agreement with EMBRAPA and FAPEMIG (Minas Gerais State Foundation for Research Development) for the fellowship of MELS. Special thanks to Marcelo Paganella from Embrapa Recursos Genéticos e Biotecnologia for maintenance of the greenhouse.

\section{References}

[1] Edmeades, G.O. (2013) Progress in Achieving and Delivering Drought Tolerance in Maize-An Update. ISAAA, Ithaca, NY.

[2] FAO (2017) The Future of Food and Agriculture: Trends and Challenges. http://www.fao.org/3/a-i6583e.pdf

[3] Weber, R.L.M., Wiebke-Strohm, B., Bredemeier, C., Margis-Pinheiro, M., Brito, G.G., Rechenmacher, C., Bertagnolli, P.F., Lisei-de-Sá, M.E., Campos, M.A., Amorim, R.M.S., Beneventi, M.A., Margis, R., Grossi-de-Sa, M.F. and Bodanese-Zanettini, M.H. (2014) Expression of an Osmotin-Like Protein from Solanum nigrum Confers Drought Tolerance in Transgenic Soybean. BMC Plant Biology, 14 343. https://doi.org/10.1186/s12870-014-0343-y

[4] Brito, G.G., Fagundes, P.R.R., Telo, G.M., Abreu, A.G., Magalhaes-Júnior, A.M., Franco, D.F., Andres, A., Parfitt, J.M.B., Kunh, R. and Petrine, J.A. (2016) Impact of Supra-Optimal Temperatures Onphysiology and Yield in Rice Field. Journal of Agricultural Science, 8, 27.

[5] ICAC (2014) Cotton, Review of the World Situation. International Cotton Advisory Committee.

[6] Ton, P. (2011) Cotton and Climate Change: Impacts and Options to Mitigate and Adapt. International Trade Centre, 1-17.

[7] Edmeades, G.O. (2008) Drought Tolerance in Maize: An Emerging Reality. International Service for the Acquisition of Agri-Biotech Applications (ISAAA).

[8] Yang, S., Vanderbeld, B., Wan, J. and Huang, Y. (2010) Narrowing Down the Targets: Towards Successful Genetic Engineering of Drought-Tolerant Crops. Molecular Plant, 3, 469-490. https://doi.org/10.1093/mp/ssq016

[9] Smith, K.A. (2000) Soil and Environmental Analysis: Physical Methods, Revised, and Expanded. CRC Press.

[10] Allen, R.D. (2012) Evaluation of Drought Tolerance Strategies in Cotton. National Agricultural Biotechnology Council, 45-63. 
[11] Shinozaki, K. and Yamaguchi-Shinozaki, K. (2007) Gene Networks Involved in Drought Stress Response and Tolerance. Journal of Experimental Botany, 58, 221-227. https://doi.org/10.1093/jxb/erl164

[12] Lawlor, D.W. (2013) Genetic Engineering to Improve Plant Performance under Drought: Physiological Evaluation of Achievements, Limitations, and Possibilities. Journal of Experimental Botany, 64, 83-108. https://doi.org/10.1093/jxb/ers326

[13] Mizoi, J., Shinozaki, K. and Yamaguchi-Shinozaki, K. (2012) AP2/ERF Family Transcription Factors in Plant Abiotic Stress Responses. Biochimica et Biophysica Acta, 1819, 86-96. https://doi.org/10.1016/j.bbagrm.2011.08.004

[14] Liu, Q., Kasuga, M., Sakuma, Y., Abe, H., Miura, S., Yamaguchi-Shinozaki, K. and Shinozaki, K. (1998) Two Transcription Factors, DREB1 and DREB2, with an EREBP/AP2 DNA Binding Domain Separate Two Cellular Signal Transduction Pathways in Drought- and Low-Temperature-Responsive Gene Expression, Respectively, in Arabidopsis. The Plant Cell, 10, 1391-1406.

https://doi.org/10.1105/tpc.10.8.1391

[15] Zhou, M.L., Ma, J.T., Pang, J.F., Zhang, Z.L., Tang, Y.X. and Wu, Y.M. (2010) Regulation of Plant Stress Response by Dehydration Responsive Element Binding (DREB) Transcription Factors. African Journal of Biotechnology, 9, 9255-9279.

[16] Kasuga, M., Liu, Q., Miura, S., Yamaguchi-Shinozaki, K. and Shinozaki, K. (1999) Improving Plant Drought, Salt, and Freezing Tolerance by Gene Transfer of a Single Stress-Inducible Transcription Factor. Nature Biotechnology, 17, 287-291. https://doi.org/10.1038/7036

[17] Polizel, A.M., Medri, M.E., Nakashima, K., Yamanaka, N., Farias, J.R.B., De Oliveira, M.C., Marin, S.R., Abdelnoor, R.V., Marcelino-Guimarães, F.C. and Fuganti, R. (2011) Molecular, Anatomical and Physiological Properties of a Genetically Modified Soybean Line Transformed with rd29A: AtDREB1A for the Improvement of Drought Tolerance. Genetics and Molecular Research, 10, 3641-3656.

https://doi.org/10.4238/2011.October.21.4

[18] Sakuma, Y., Maruyama, K., Osakabe, Y., Qin, F., Seki, M., Shinozaki, K. and Yamaguchi-Shinozaki, K. (2006) Functional Analysis of an Arabidopsis Transcription Factor, DREB2A, Involved in Drought-Responsive Gene Expression. The Plant Cell, 18, 1292-1309. https://doi.org/10.1105/tpc.105.035881

[19] Maruyama, K., Takeda, M., Kidokoro, S., Yamada, K., Sakuma, Y., Urano, K., Fujita, M., Yoshiwara, K., Matsukura, S., Morishita, Y., Sasaki, R., Suzuki, H., Saito, K., Shibata, D., Shinozaki, K. and Yamaguchi-Shinozaki, K. (2009) Metabolic Pathways Involved in Cold Acclimation Identified by Integrated Analysis of Metabolites and Transcripts Regulated by DREB1A and DREB2A. Plant Physiology, 150, 1972-1980. https://doi.org/10.1104/pp.109.135327

[20] Agarwal, M., Hao, Y., Kapoor, A., Dong, C.H., Fujii, H., Zheng, X. and Zhu, J.K. (2006) A R2R3 Type MYB Transcription Factor Is Involved in the Cold Regulation of CBF Genes and in Acquired Freezing Tolerance. Journal of Biological Chemistry, 281, 37636-37645. https://doi.org/10.1074/jbc.M605895200

[21] Lata, C., Yadav, A. and Prasad, M. (2011) Role of Plant Transcription Factors in Abiotic Stress Tolerance.

[22] Rehman, S. and Mahmood, T. (2015) Functional Role of DREB and ERF Transcription Factors: Regulating Stress-Responsive Network in Plants. Acta Physiologiae Plantarum, 37, 178. https://doi.org/10.1007/s11738-015-1929-1

[23] Agarwal, P.K., Gupta, K., Lopato, S. and Agarwal, P. (2017) Dehydration Respon- 
sive Element Binding Transcription Factors and Their Applications for the Engineering of Stress Tolerance. Journal of Experimental Botany, 68, 2135-2148. https://doi.org/10.1093/jxb/erx118

[24] Kasuga, M., Miura, S., Shinozaki, K. and Yamaguchi-Shinozaki, K. (2004) A Combination of the Arabidopsis DREB1A Gene and Stress-Inducible rd29A Promoter Improved Drought- and Low-Temperature Stress Tolerance in Tobacco by Gene Transfer. Plant and Cell Physiology, 45, 346-350. https://doi.org/10.1093/pcp/pch037

[25] Mishra, N., Sun, L., Zhu, X., Smith, J., Prakash Srivastava, A., Yang, X., Pehlivan, N., Esmaeili, N., Luo, H., Shen, G., Jones, D., Auld, D., Burke, J., Payton, P. and Zhang, H. (2017) Overexpression of the Rice SUMO E3 Ligase Gene OsSIZ1 in Cotton Enhances Drought and Heat Tolerance, and substantially Improves Fiberyields in the Field under Reduced Irrigation and Rainfed Conditions. Plant \& Cell Physiology, 58, 735-746. https://doi.org/10.1093/pcp/pcx032

[26] Kerr, T.C., Abdel-Mageed, H., Aleman, L., Lee, J., Payton, P., Cryer, D. and Allen, R.D. (2017) Ectopic Expression of Two AREB/ABF Orthologs Increases Drought Tolerance in Cotton (Gossypium hirsutum). Plant, Cell \& Environment, 18, 12906.

[27] Yan, J., He, C., Wang, J., Mao, Z., Holaday, S.A., Allen, R.D. and Zhang, H. (2004) Overexpression of the Arabidopsis 14-3-3 Protein GF14 $\lambda$ in Cotton Leads to a "Stay-Green" Phenotype and Improves Stress Tolerance under Moderate Drought Conditions. Plant and Cell Physiology, 45, 1007-1014. https://doi.org/10.1093/pcp/pch115

[28] He, C., Yan, J., Shen, G., Fu, L., Holaday, A.S., Auld, D., Blumwald, E. and Zhang, H. (2005) Expression of an Arabidopsis Vacuolar Sodium/Proton Antiporter Gene in Cotton Improves Photosynthetic Performance under Salt Conditions and Increases Fiber Yield in the Field. Plant and Cell Physiology, 46, 1848-1854. https://doi.org/10.1093/pcp/pci201

[29] Maqbool, A., Abbas, W., Rao, A.Q., Irfan, M., Zahur, M., Bakhsh, A., Riazuddin, S. and Husnain, T. (2010) Gossypium arboreum GHSP26 Enhances Drought Tolerance in Gossypium hirsutum. Biotechnology Progress, 26, 21-25.

[30] Momtaz, O.A., Hussein, E.M., Fahmy, E.M. and Ahmed, S.E. (2010) Expression of S-Adenosyl Methionine Decarboxylase Gene for Polyamine Accumulation in Egyptian cotton Giza 88 and Giza 90. GM Crops, 1, 257-266. https://doi.org/10.4161/gmcr.1.4.13779

[31] Shi, J., Zhang, L., An, H., Wu, C. and Guo, X. (2011) GhMPK16, a Novel Stress-Responsive Group D MAPK Gene from Cotton, Is Involved in Disease Resistance and Drought Sensitivity. BMC Molecular Biology, 12, 22.

https://doi.org/10.1186/1471-2199-12-22

[32] Pasapula, V., Shen, G., Kuppu, S., Paez-Valencia, J., Mendoza, M., Hou, P., Chen, J., Qiu, X., Zhu, L. and Zhang, X. (2011) Expression of an Arabidopsis Vacuolar $\mathrm{H}^{+}$Pyrophosphatase Gene (AVP1) in Cotton Improves Drought and Salt Tolerance and Increases Fibre Yield in the Field Conditions. Plant Biotechnology Journal, 9, 88-99. https://doi.org/10.1111/j.1467-7652.2010.00535.x

[33] Yue, Y., Zhang, M., Zhang, J., Tian, X., Duan, L. and Li, Z. (2012) Overexpression of the AtLOS5 Gene Increased Abscisic Acid Level and Drought Tolerance in Transgenic Cotton. Journal of Experimental Botany, 63, 3741-3748. https://doi.org/10.1093/jxb/ers069

[34] Shamim, Z., Rashid, B., Rahman, S. and Husnain, T. (2013) Expression of Drought Tolerance in Transgenic Cotton. Science Asia, 39, 1-11. 
https://doi.org/10.2306/scienceasia1513-1874.2013.39.001

[35] Kuppu, S., Mishra, N., Hu, R., Sun, L., Zhu, X., Shen, G., Blumwald, E., Payton, P. and Zhang, H. (2013) Water-Deficit Inducible Expression of a Cytokinin Biosynthetic Gene IPT Improves Drought Tolerance in Cotton. PLoS ONE, 8, e64190. https://doi.org/10.1371/journal.pone.0064190

[36] Liu, G., Li, X., Jin, S., Liu, X., Zhu, L., Nie, Y. and Zhang, X. (2014) Overexpression of Rice NAC Gene SNAC1 Improves Drought and Salt Tolerance by Enhancing Root Development and Reducing Transpiration Rate in Transgenic Cotton. PLoS ONE, 9, e86895. https://doi.org/10.1371/journal.pone.0086895

[37] Zhang, F., Li, S., Yang, S., Wang, L. and Guo, W. (2015) Overexpression of a Cotton Annexin Gene, GhAnn1, Enhances Drought and Salt Stress Tolerance in Transgenic Cotton. Plant Molecular Biology, 87, 47-67. https://doi.org/10.1007/s11103-014-0260-3

[38] Gunapati, S., Naresh, R., Ranjan, S., Nigam, D., Hans, A., Verma, P.C., Gadre, R., Pathre, U.V., Sane, A.P. and Sane, V.A. (2016) Expression of GhNAC2 from $G$. herbaceum, Improves Root Growth and Imparts Tolerance to Drought in Transgenic Cotton and Arabidopsis. Scientific Reports, 6, 24978. https://doi.org/10.1038/srep24978

[39] Liang, C., Meng, Z., Meng, Z., Malik, W., Yan, R., Lwin, K.M., Lin, F., Wang, Y., Sun, G., Zhou, T., Zhu, T., Li, J., Jin, S., Guo, S. and Zhang, R. (2016) GhABF2, a bZIP Transcription Factor, Confers Drought and Salinity Tolerance in Cotton (Gossypium hirsutum L.), Scientific Reports, 6, 35040. https://doi.org/10.1038/srep35040

[40] Rahnama, A., James, R.A., Poustini, K. and Munns, R. (2010) Stomatal Conductance as a Screen for Osmotic Stress Tolerance in Durum Wheat Growing in Saline Soil. Functional Plant Biology, 37, 255-263. https://doi.org/10.1071/FP09148

[41] Flexas, J., Bota, J., Galmes, J., Medrano, H. and Ribas-Carbó, M. (2006) Keeping a Positive Carbon Balance under Adverse Conditions: Responses of Photosynthesis and Respiration to Water Stress. Physiologia Plantarum, 127, 343-352. https://doi.org/10.1111/j.1399-3054.2006.00621.x

[42] Mafakheri, A., Siosemardeh, A.F., Bahramnejad, B., Struik, P.C. and Sohrabi, Y. (2010) Effect of Drought Stress on Yield, Proline and Chlorophyll Contents in Three Chickpea Cultivars. Journal of Crop Science, 4, 777-780.

[43] Gregory, P.J., Atkinson, C.J., Bengough, A.G., Else, M.A., Fernandez-Fernandez, F., Harrison, R.J. and Schmidt, S. (2013) Contributions of Roots and Rootstocks to Sustainable, Intensified Crop Production. Journal of Experimental Botany, 64, 1209-1222. https://doi.org/10.1093/jxb/ers385

[44] Vianna, G.R., Aragao, F.J.L. and Rech, E.L. (2011) A Minimal DNA Cassette as a Vector for Genetic Transformation of Soybean (Glycine max). Genetics and Molecular Research, 10, 382-390. https://doi.org/10.4238/vol10-1gmr1058

[45] Engels, C., Fuganti-Pagliarini, R., Marin, S.R., Marcelino-Guimaraes, F.C., Oliveira, M.C., Kanamori, N., Mizoi, J., Nakashima, K., Yamaguchi-Shinozaki, K. and Nepomuceno, A.L. (2013) Introduction of the rd29A:AtDREB2A-CA Gene into Soybean (Glycine $\max$ L. Merril) and Its Molecular Characterization in Leaves and Roots during Dehydration. Genetics and Molecular Biology, 36, 556-565. https://doi.org/10.1590/S1415-47572013000400015

[46] Aragão, F.J.L., Sarokin, L., Vianna, G.R. and Rech, E.L. (2000) Selection of Transgenic Meristematic Cells Utilizing a Herbicidal Molecule Results in the Recovery of 
Fertile Transgenic Soybean [Glycine max (L.) Merril] Plants at a High Frequency. Theoretical and Applied Genetics, 101, 1-6. https://doi.org/10.1007/s001220051441

[47] Rech, E.L., Vianna, G.R. and Aragao, F.J.L. (2008) High-Efficiency Transformation by Biolistics of Soybean, Common Bean and Cotton Transgenic Plants. Nature Protocols, 3, 410-418. https://doi.org/10.1038/nprot.2008.9

[48] Michiels, A., Van-den-Ende, W., Tucker, M., Van-Riet, L. and Van-Laere, A. (2003) Extraction of High-Quality Genomic DNA from Latex-Containing Plants. Analytical Biochemistry, 315, 85-89. https://doi.org/10.1016/S0003-2697(02)00665-6

[49] McDonald, M.B., Elliot, L.J. and Sweeney, P.M. (1997) DNA Extraction from Dry Seeds for RAPD Analyses. In: Ellis, R.H., Black, M., Murdoch, A.J. and Hong, T.D., Eds., Basic and Applied Aspects of Seed Biology: Proceedings of the Fifth International Workshop on Seeds, Reading, Springer, Netherlands, Dordrecht, 747-753. https://doi.org/10.1007/978-94-011-5716-2_81

[50] Zhao, S. and Fernald, R.D. (2005) Comprehensive Algorithm for Quantitative Real-Time Polymerase Chain Reaction. Journal of Computational Biology, 12, 1047-1064. https://doi.org/10.1089/cmb.2005.12.1047

[51] Hellemans, J., Mortier, G., De Paepe, A., Speleman, F. and Vandesompele, J. (2007) qBase Relative Quantification Framework and Software for Management and Automated Analysis of Real-Time Quantitative PCR Data. Genome Biology, 8, R19. https://doi.org/10.1186/gb-2007-8-2-r19

[52] Yang, X., Li, F., Liu, C., Zhang, X., Liu, K., Fang, W., Wu, Z., Xie, D., Zhang, C., Wang, Q. and Zhao, F. (2012) Analysis of the Copy Number of Exogenous Genes in Transgenic Cotton Using Real-Time Quantitative PCR and the $2^{-\Delta \Delta}{ }^{\mathrm{Ct}}$ Method. African Journal of Biotechnology, 11, 6226-6233.

[53] Ribeiro, T.P., Arraes, F.B.M., Lourenco-Tessutti, I.T., Silva, M.S., Lisei-de-Sa, M.E., Lucena, W.A., Macedo, L.L.P., Lima, J.N., Santos Amorim, R.M., Artico, S., Alves-Ferreira, M., Mattar Silva, M.C. and Grossi-de-Sa, M.F. (2017) Transgenic Cotton Expressing Cry10Aa Toxin Confers High Resistance to the Cotton Boll Weevil. Plant Biotechnology Journal, 15, 997-1009. https://doi.org/10.1111/pbi.12694

[54] Hoagland, D.R. and Arnon, D.I. (1938) The Water-Culture Method for Growing Plants without Soil. University of California.

[55] Marani, A., Baker, D.N., Reddy, V.R. and McKinion, J.M. (1985) Effect of Water Stress on Canopy Senescence and Carbon Exchange Rates in Cotton. Crop Science, 25, 798-802. https://doi.org/10.2135/cropsci1985.0011183X0025000500018x

[56] Jordan, W.R. and Ritchie, J.T. (1971) Influence of Soil Water Stress on Evaporation, Root Absorption, and Internal Water Status of Cotton. Plant Physiology, 48, 783-788. https://doi.org/10.1104/pp.48.6.783

[57] Blum, A. (1989) Osmotic Adjustment and Growth of Barley Genotypes under Drought Stress. Crop Science, 29, 230-233. https://doi.org/10.2135/cropsci1989.0011183X002900010052x

[58] Brito, G.G., Sofiatti, V., Lima, M.M.A., Carvalho, L.P. and Silva-Filho, J.L. (2011) Physiological Traits for Drought Phenotyping in Cotton. Acta Scientiarum Agronomy, 33, 117-125. https://doi.org/10.4025/actasciagron.v33i1.9839

[59] Chen, L., Auh, C.K., Dowling, P., Bell, J., Chen, F., Hopkins, A., Dixon, R.A. and Wang, Z.Y. (2003) Improved Forage Digestibility of Tall Fescue (Festuca arundinacea) by Transgenic Down-Regulation of Cinnamyl Alcohol Dehydrogenase. Plant Biotechnology Journal, 1, 437-449. https://doi.org/10.1046/j.1467-7652.2003.00040.x 
[60] Wang, Z.Y., Bell, J., Ge, Y.X. and Lehmann, D. (2003) Inheritance of Transgenes in Transgenic Tall Fescue (Festuca arundinacea schreb.). In Vitro Cellular \& Developmental Biology_Plant, 39, 277-282. https://doi.org/10.1079/IVP2002392

[61] Morran, S., Eini, O., Pyvovarenko, T., Parent, B., Singh, R., Ismagul, A., Eliby, S., Shirley, N., Langridge, P. and Lopato, S. (2011) Improvement of Stress Tolerance of Wheat and Barley by Modulation of Expression of DREB/CBF Factors. Plant Biotechnology Journal, 9, 230-249. https://doi.org/10.1111/j.1467-7652.2010.00547.x

[62] Bhatnagar-Mathur, P., Rao, J.S., Vadez, V., Dumbala, S.R., Rathore, A., Yamaguchi-Shinozaki, K. and Sharma, K.K. (2014) Transgenic Peanut Overexpressing the DREB1A Transcription Factor Has Higher Yields under Drought Stress. Molecular Breeding, 33, 327-340. https://doi.org/10.1007/s11032-013-9952-7

[63] Bihani, P., Char, B. and Bhargava, S. (2011) Transgenic Expression of Sorghum DREB2 in Rice Improves Tolerance and Yield under Water Limitation. Journal of Agricultural Science, 149, 95-101. https://doi.org/10.1017/S0021859610000742

[64] Pellegrineschi, A., Reynolds, M., Pacheco, M., Brito, R.M., Almeraya, R., Yamaguchi-Shinozaki, K. and Hoisington, D. (2004) Stress-Induced Expression in Wheat of the Arabidopsis thaliana DREB1A Gene Delays Water Stress Symptoms under Greenhouse Conditions. Genome, 47, 493-500. https://doi.org/10.1139/g03-140

[65] Soltesz, A., Smedley, M., Vashegyi, I., Galiba, G., Harwood, W. and Vagujfalvi, A. (2013) Transgenic Barley Lines Prove the Involvement of TaCBF14 and TaCBF15 in the Cold Acclimation Process and in Frost Tolerance. Journal of Experimental Botany, 64, 1849-1862. https://doi.org/10.1093/jxb/ert050

[66] Dubouzet, J.G., Sakuma, Y., Ito, Y., Kasuga, M., Dubouzet, E.G., Miura, S., Seki, M., Shinozaki, K. and Yamaguchi-Shinozaki, K. (2003) OsDREB Genes in Rice, Oryza sativa L., Encode Transcription Activators That Function in Drought-, High-Saltand Cold-Responsive Gene Expression. Plant Journal, 33, 751-763. https://doi.org/10.1046/j.1365-313X.2003.01661.x

[67] Shen, Y.G., Zhang, W.K., He, S.J., Zhang, J.S., Liu, Q. and Chen, S.Y. (2003) An EREBP/AP2-Type Protein in Triticum aestivum Was a DRE-Binding Transcription Factor Induced by Cold, Dehydration and ABA Stress. Theoretical and Applied Genetics, 106, 923-930. https://doi.org/10.1007/s00122-002-1131-x

[68] Oh, S.J., Song, S.I., Kim, Y.S., Jang, H.J., Kim, S.Y., Kim, M., Kim, Y.K., Nahm, B.H. and Kim, J.K. (2005) Arabidopsis CBF3/DREB1A and ABF3 in Transgenic Rice Increased Tolerance to Abiotic Stress without Stunting Growth. Plant Physiology, 138, 341-351. https://doi.org/10.1104/pp.104.059147

[69] Yamaguchi-Shinozaki, K. and Shinozaki, K. (1993) Characterization of the Expression of a Desiccation-Responsive rd29 Gene of Arabidopsis thaliana and Analysis of Its Promoter in Transgenic Plants. Molecular and General Genetics, 236, 331-340. https://doi.org/10.1007/BF00277130

[70] Bihmidine, S., Lin, J., Stone, J.M., Awada, T., Specht, J.E. and Clemente, T.E. (2013) Activity of the Arabidopsis RD29A and RD29B Promoter Elements in Soybean Under Water Stress. Planta, 237, 55-64. https://doi.org/10.1007/s00425-012-1740-9

[71] Sakuma, Y., Maruyama, K., Qin, F., Osakabe, Y., Shinozaki, K. and Yamaguchi-Shinozaki, K. (2006) Dual Function of an Arabidopsis Transcription Factor DREB2A in Water-Stress-Responsive and Heat-Stress-Responsive Gene Expression. Proceedings of the National Academy of Sciences, 103, 18822-18827. https://doi.org/10.1073/pnas.0605639103

[72] Schramm, F., Larkindale, J., Kiehlmann, E., Ganguli, A., Englich, G., Vierling, E. and Koskull-Doring, V. (2008) A Cascade of Transcription Factor DREB2A and 
Heat Stress Transcription Factor HsfA3 Regulates the Heat Stress Response of Arabidopsis. Plant Journal, 53, 264-274. https://doi.org/10.1111/j.1365-313X.2007.03334.x

[73] Reis, R.R., Cunha, B.A.D.B., Martins, P.K., Martins, M.T.B., Alekcevetch, J.C., Chalfun-Junior, A., Andrade, A.C., Ribeiro, A.P., Qin, F. and Mizoi, J. (2014) Induced Over-Expression of AtDREB2A-CA Improves Drought Tolerance in Sugarcane. Plant Science, 221, 59-68. https://doi.org/10.1016/j.plantsci.2014.02.003

[74] Pruthvi, V., Narasimhan, R. and Nataraja, K.N. (2014) Simultaneous Expression of Abiotic Stress Responsive Transcription Factors, AtDREB2A, AtHB7 and AtABF3 Improves Salinity and Drought Tolerance in Peanut (Arachis hypogaea L.). PLoS ONE, 9, e111152. https://doi.org/10.1371/journal.pone.0111152

[75] Wilson, C., Bellen, H.J. and Gehring, W.J. (1990) Position Effects on Eukaryotic Gene Expression. Annual Review of Cell Biology, 6, 679-714. https://doi.org/10.1146/annurev.cb.06.110190.003335

[76] Heinrichs, A. (2008) Small RNAs: United in Silence. Nature Reviews, 9, 496-496. https://doi.org/10.1038/nrm2429

[77] Brito, G.G., Suassuna, N.D., Diola, V., Sofiatti, V., Ducatti, C., Silva, E.T. and Morello, C.L. (2014) Carbon Isotope Fractionation for Cotton Genotype Selection. Pesquisa Agropecuária Brasileira, 49, 673-682. https://doi.org/10.1590/S0100-204X2014000900003

[78] Vadez, V., Rao, J.S., Bhatnagar-Mathur, P. and Sharma, K.K. (2013) DREB1A Promotes Root Development in Deep Soil Layers and Increases Water Extraction under Water Stress in Groundnut. Plant Biology, 15, 45-52. https://doi.org/10.1111/j.1438-8677.2012.00588.x

[79] Larcher, W. (2000) Temperature Stress and Survival Ability of Mediterranean Sclerophyllous Plants. Plant Biosystems, 134, 279-295. https://doi.org/10.1080/11263500012331350455

[80] Isoda, A. and Wang, P. (2002) Leaf Temperature and Transpiration of Field Grown Cotton and Soybean under Arid and Humid Conditions. Plant Production Science, 5, 224-228. https://doi.org/10.1626/pps.5.224

[81] Barnabas, B., Jager, K. and Feher, A. (2008) The Effect of Drought and Heat Stress on Reproductive Processes in Cereals. Plant, Cell \& Environment, 31, 11-38.

[82] O’Neill, S.D. (1983) Role of Osmotic Potential Gradients during Water Stress and Leaf Senescence in Fragaria virginiana. Plant Physiology, 72, 931-937. https://doi.org/10.1104/pp.72.4.931

[83] Suarez, N. and Sobrado, M.A. (2000) Adjustments in Leaf Water Relations of Mangrove (Avicennia germinans) Seedlings Grown in a Salinity Gradient. Tree Physiology, 20, 277-282. https://doi.org/10.1093/treephys/20.4.277

[84] Patakas, A., Nikolaou, N., Zioziou, E., Radoglou, K. and Noitsakis, B. (2002) The Role of Organic Solute and Ion Accumulation in Osmotic Adjustment in Drought-Stressed Grapevines. Plant Science, 163, 361-367.

https://doi.org/10.1016/S0168-9452(02)00140-1

[85] Quarrie, S.A., Stojanovic, J. and Pekic, S. (1999) Improving Drought Resistance in Small-Grained Cereals: A Case Study, Progress and Prospects. Plant Growth Regulation, 29, 1-21. https://doi.org/10.1023/A:1006210722659

[86] Serraj, R. and Sinclair, T.R. (2002) Osmolyte Accumulation: Can It Really Help Increase Crop Yield under Drought Conditions? Plant, Cell \& Environment, 25, 333-341. https://doi.org/10.1046/j.1365-3040.2002.00754.x 


\section{Supporting Information}

Additional File 1-Table S1. Transformed cotton plants tolerant to water stress.

\begin{tabular}{|c|c|c|c|c|c|}
\hline Gene inserted & Gene product and function & Promoter & $\begin{array}{l}\text { Transformation } \\
\text { method }\end{array}$ & $\begin{array}{l}\text { Stress } \\
\text { tolerance }\end{array}$ & References \\
\hline AtGF14ג & $\begin{array}{l}14-3-3 \text { protein regulates primary } \\
\text { metabolism, ion transport, cellular traffic, } \\
\text { enzyme activities and gene expression. }\end{array}$ & CAMV $35 S$ & $\begin{array}{l}\text { Agrobacterium } \\
\text { tumefaciens }\end{array}$ & Drought & Yan et al., 2004 \\
\hline AtNHX1 & $\begin{array}{l}\text { Vacuolar sodium/proton antiporter that } \\
\text { mediates the exchange of cytosolic } \mathrm{Na}^{+} \text {for } \\
\text { vacuolar } \mathrm{H}^{+} \text {. }\end{array}$ & Supermas & $\begin{array}{l}\text { Agrobacterium } \\
\text { tumefaciens }\end{array}$ & $\begin{array}{l}\text { Drought, } \\
\text { Salinity }\end{array}$ & He et al., 2005 \\
\hline GaHSP26 & $\begin{array}{l}\text { Molecular chaperones that assist in protein } \\
\text { folding and prevent protein denaturation. }\end{array}$ & CAMV $35 S$ & $\begin{array}{l}\text { Agrobacterium } \\
\text { tumefaciens }\end{array}$ & Drought & Maqbool et al., 2010 \\
\hline SceSAMDC & $\begin{array}{l}\text { SAMDC catalyzes S-adenosyl methionine } \\
\text { (SAM) to form decarboxylated SAM. }\end{array}$ & CAMV $35 S$ & $\begin{array}{c}\text { Particle } \\
\text { bombardment }\end{array}$ & Drought & Momtaz et al., 2010 \\
\hline GhMPK16 & $\begin{array}{l}\text { Mitogen-activated protein kinase (MAPK) } \\
\text { gene that plays a role in mediating biotic } \\
\text { and abiotic stress responses. }\end{array}$ & CAMV $35 S$ & $\begin{array}{l}\text { Agrobacterium } \\
\text { tumefaciens }\end{array}$ & $\begin{array}{l}\text { Drought, } \\
\text { Pathogen }\end{array}$ & Shi et al., 2011 \\
\hline AtAVP1 & $\begin{array}{l}\text { Vacuolar pyrophosphatase that functions } \\
\text { as a proton pump on the vacuolar } \\
\text { membrane. }\end{array}$ & CAMV $35 S$ & $\begin{array}{l}\text { Agrobacterium } \\
\text { tumefaciens }\end{array}$ & $\begin{array}{l}\text { Drought, } \\
\text { Salinity }\end{array}$ & Pasapula et al., 2011 \\
\hline AtLOS5 & $\begin{array}{l}\text { Molybdenum co-factor, essential for } \\
\text { activating aldehyde oxidase, which is } \\
\text { involved in the hormone abscisic acid } \\
\text { (ABA) biosynthesis. }\end{array}$ & CAMV $35 S$ & $\begin{array}{l}\text { Agrobacterium } \\
\text { tumefaciens }\end{array}$ & Drought & Yue et al., 2012 \\
\hline GHSP26 & $\begin{array}{l}\text { Molecular chaperones that assist in protein } \\
\text { folding and prevent protein denaturation. }\end{array}$ & CaMV 35S & $\begin{array}{l}\text { Agrobacterium } \\
\text { tumefaciens }\end{array}$ & Drought & Shamim et al., 2013 \\
\hline GUSP1 & $\begin{array}{l}\text { Bacteria, archaea, fungi, flies, and plants } \\
\text { protein which show specific expression } \\
\text { patterns during drought stress. }\end{array}$ & CaMV 35S & $\begin{array}{l}\text { Agrobacterium } \\
\text { tumefaciens }\end{array}$ & Drought & Shamim et al., 2013 \\
\hline Phyto-B & $\begin{array}{l}\text { Controls the transition from vegetative to } \\
\text { reproductive growth, seedling } \\
\text { establishment and entrainment of } \\
\text { circadian clock. }\end{array}$ & CaMV 35S & $\begin{array}{l}\text { Agrobacterium } \\
\text { tumefaciens }\end{array}$ & Drought & Shamim et al., 2013 \\
\hline AtulPT & $\begin{array}{l}\text { Isopentenyltransferase, which has a role in } \\
\text { cytokinin biosynthesis }\end{array}$ & pSARK & $\begin{array}{l}\text { Agrobacterium } \\
\text { tumefaciens }\end{array}$ & Drought & Kuppu et al., 2013 \\
\hline OsSNAC1 & NAC transcription factor & CaMV 35S & $\begin{array}{l}\text { Agrobacterium } \\
\text { tumefaciens }\end{array}$ & $\begin{array}{l}\text { Drought, } \\
\text { Salinity }\end{array}$ & Liu et al., 2014 \\
\hline GhAnn1 & Putative annexin protein & CaMV 355 & $\begin{array}{l}\text { Agrobacterium } \\
\text { tumefaciens }\end{array}$ & $\begin{array}{l}\text { Drought, } \\
\text { Salinity }\end{array}$ & Zhang et al., 2015 \\
\hline GhNAC2 & NAC transcription factor & CaMV 35S & $\begin{array}{l}\text { Agrobacterium } \\
\text { tumefaciens }\end{array}$ & Drought & Gunapati et al, 2016 \\
\hline GhABF2 & bZIP transcription factor & CaMV $35 S$ & $\begin{array}{l}\text { Agrobacterium } \\
\text { tumefaciens }\end{array}$ & $\begin{array}{l}\text { Drought, } \\
\text { Salinity }\end{array}$ & Liang et al., 2016 \\
\hline AtABF3 & $A B A-r e s p o n s i v e$ element binding factor & CaMV 35S & $\begin{array}{l}\text { Agrobacterium } \\
\text { tumefaciens }\end{array}$ & Drought & Kerr et al., 2017 \\
\hline GhABF2D & ABA-responsive element binding factor & CaMV 35S & $\begin{array}{l}\text { Agrobacterium } \\
\text { tumefaciens }\end{array}$ & Drought & Kerr et al., 2017 \\
\hline OssIZ1 & SUMO E3 Ligase & $p Z m U b i$ & $\begin{array}{l}\text { Agrobacterium } \\
\text { tumefaciens }\end{array}$ & $\begin{array}{l}\text { Drought, } \\
\text { Heat }\end{array}$ & Mishra et al., 2017 \\
\hline ZmABP9 & bZIP transcription factor & CaMV 355 & $\begin{array}{l}\text { Agrobacterium } \\
\text { tumefaciens }\end{array}$ & $\begin{array}{l}\text { Drought, } \\
\text { Salinity }\end{array}$ & Wang et al., 2017 \\
\hline AtDREB2A-CA & DRE binding proteins. & $r d 29 A$ & $\begin{array}{c}\text { Particle } \\
\text { bombardment }\end{array}$ & Drought & This report \\
\hline
\end{tabular}

Abbreviations: At - Arabidopsis thaliana; Atu - Agrobacterium tumefaciens; Ga - Gossypium arboreum; Gh - Gossypium hirsutum; Os - Oriza sativa; Sce - Saccharomyces cerevisiae; Zm - Zea mays. 
Additional File 2-Table S2. Summary of the used primers.

\begin{tabular}{|c|c|c|c|c|}
\hline Primer name & Sequence (5'-3') & $\mathrm{T}_{\mathrm{M}}\left({ }^{\circ} \mathrm{C}\right)^{1}$ & Amplicon length (bp) & Assays \\
\hline M-Fow & AAT GGT GCG GAA GAG ATG AA & \multirow{2}{*}{55} & \multirow{2}{*}{450} & \multirow{2}{*}{$\begin{array}{l}\text { Detection of pBSK-rd29A::AtDREB2A-CA-NOSt } \\
\text { transformation cassette in transgenic cotton plants. }\end{array}$} \\
\hline M-Rev & GTT CTC CAG ATC CAA GTA AC & & & \\
\hline qPCR-Fow & TGT TTGA TGT CGA TGA GCT TCT & \multirow[b]{2}{*}{60} & \multirow[b]{2}{*}{173} & \multirow{2}{*}{$\begin{array}{l}\text { Determination of transgene transcript levels and } \\
\text { cassette copy number in GM cotton plants (RT- } \\
\text { qPCR). }\end{array}$} \\
\hline qPCR-Rev & CTG AAA CGG AGG TAT TCC GTA G & & & \\
\hline GhUBQ14-Fow & CAA CGC TCC ATC TTG TCC TT & \multirow{2}{*}{60} & \multirow{2}{*}{75} & \multirow{2}{*}{$\begin{array}{l}\text { Determination of transgene transcript levels in GM } \\
\text { cotton plants (RT-qPCR). }\end{array}$} \\
\hline GhUBQ14-Rev & TGA TCG TCT TTC CCG TAA GC & & & \\
\hline GhPP2A1-Fow & GAT CCT TGT GGA GGA GTG GA & \multirow{2}{*}{60} & \multirow{2}{*}{100} & \multirow{2}{*}{$\begin{array}{l}\text { Determination of transgene transcript levels in GM } \\
\text { cotton plants (RT-qPCR). }\end{array}$} \\
\hline GhPP2A1-Rev & GCG AAA CAG TTC GAC GAG AT & & & \\
\hline GhUBC1-Fow & TGG CAT TAT ATT GTC ATT GTT ACT ATC C & \multirow{2}{*}{60} & \multirow{2}{*}{121} & \multirow{2}{*}{$\begin{array}{l}\text { Determination of cassette copy number in } \\
\text { transgenic cotton genome. }\end{array}$} \\
\hline GhUBC1-Rev & ACC ATG TTA TCT TAT TCT AAG ACA AGC TC & & & \\
\hline
\end{tabular}

'Anneling (or melting) temperature used in experiments.

Additional File 3-Table S3. Transgenic plants transformed with AtDREB2A.

\begin{tabular}{cccc}
\hline Species & Promoter & Tolerance test & References \\
\hline Arabidopsis thaliana & CaMV 35S & Not shown & Liu et al., 1998 \\
Arabidopsis. thaliana & $\begin{array}{c}\text { CaMV 35S } \\
\text { rd29A }\end{array}$ & $\begin{array}{c}\text { Drought } \\
\text { Freezing } \\
\text { Drabidopsis thaliana }\end{array}$ & Sakuma et al., 2006a \\
Tobacco cells & CaMV 35S & $\begin{array}{c}\mathrm{H}_{2} \mathrm{O}_{2} \\
\text { Heat Shock }\end{array}$ & Sakuma et al., 2006b \\
Soybean & rd29A & $\begin{array}{c}\text { No one } \\
\text { Drought }\end{array}$ & Schramm et al., 2008 \\
Sugarcane & rab17 & Drought & Reis et al., 2014 \\
Peanut & CaMV 35S & $\begin{array}{c}\text { Drought } \\
\text { Salinity }\end{array}$ & Pruthvi et al., 2014 \\
& & &
\end{tabular}


Additional File 4-Table S4. Analyses performed to screen transgenic cotton tolerant to water stress.

\begin{tabular}{|c|c|c|c|c|c|c|c|c|c|c|c|c|c|c|c|c|c|}
\hline \multirow{3}{*}{$\begin{array}{l}\text { INSERTED } \\
\text { GENES }\end{array}$} & \multicolumn{16}{|c|}{ ASSAYS } & \multirow{3}{*}{ REFERENCES } \\
\hline & \multicolumn{6}{|c|}{ MOLECULAR ANALYYIS } & \multicolumn{6}{|c|}{ PHYSIILOOGICAL ANALYYSIS } & \multicolumn{3}{|c|}{ MORPHOLOGICAL ANALYSIS } & \multirow{2}{*}{ OTHER ASSAYS } & \\
\hline & PCR & Southern blot & Northern blot & qPCR & \begin{tabular}{|l|} 
western blot \\
\end{tabular} & ELISA & Photosynthesis & $\begin{array}{l}\text { Wator use } \\
\text { efficiency }\end{array}$ & $\begin{array}{c}\text { Transpiration } \\
\text { rate }\end{array}$ & $\begin{array}{l}\text { Chlorophyl } \\
\text { content }\end{array}$ & $\begin{array}{c}\text { Stomatal } \\
\text { conductance }\end{array}$ & $\begin{array}{l}\text { Intercellular } \\
\text { cartoon }\end{array}$ & Biomass & $\begin{array}{l}\begin{array}{c}\text { Fiber } \\
\text { content }\end{array} \\
\text { cols }\end{array}$ & $\begin{array}{l}\text { Phenotype } \\
\text { differences }\end{array}$ & & \\
\hline$A \mid G F 14 \lambda$ & Yes & Yes & & & & & Yes & Yes & & Yes & Yes & & & & Yes & $\begin{array}{l}\text { Intercellular to ambient } \mathrm{CO}_{2} \\
\text { concentration ratio }\end{array}$ & Yan et al, 2004 \\
\hline$A E N H X T$ & Yes & & Yes & & Yes & & Yes & & & & & & & Yes & Yes & $\begin{array}{l}\text { Nitrate reductase activity and } \\
\text { field tests }\end{array}$ & He et al, 2005 \\
\hline $\operatorname{GasP} 26$ & res & & & Yes & & & & & & & & & & & res & $\begin{array}{l}\text { Immunohistochemical } \\
\text { localization }\end{array}$ & Maabool et al., 2010 \\
\hline SAMDC & Yes & Yes & & Yes & & & & & & & & & & & Yes & $\begin{array}{l}\text { Transtormed protein } \\
\text { concentration through HLLC }\end{array}$ & Momtaz et al.. 2010 \\
\hline GHMPK16 & Yes & Yes & & & & & & & & & & & & & Yes & $\begin{array}{l}\text { Immunohistochemical } \\
\text { locaiizztion and } R_{\text {papid }} \mathrm{H}_{2} \mathrm{O}_{2} \\
\text { accummlation }\end{array}$ & Shi et al., 2011 \\
\hline AtLos5 & Yes & & & Yes & & & & & Yes & & & & & & &  & Yue et al., 2012 \\
\hline GHSP26 & Yes & & & Yes & & & & & & & & & & & Yes & 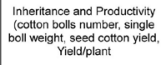 & Shamim et al., 2013 \\
\hline GUSP1 & Yes & & & Yes & & & & & & & & & & & Yes & 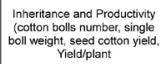 & Shamim et al., 2013 \\
\hline Phyto-B $B$ & Yes & & & Yes & & & & & & & & & & & Yes & 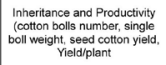 & Shamim et al., 2013 \\
\hline IPT & res & Yes & Yes & Yes & & & Yes & & Yes & Yes & & & Yes & Yes & Yes & $\begin{array}{l}\text { Number of bolls per plant and } \\
\text { internal carbon }\end{array}$ & Kuppu et al, 2013 \\
\hline SNACA & Yes & Yes & Yes & & & & Yes & & Yes & & Yes & & Yes & & Yes & $\begin{array}{l}\text { Proline and Malondialdehyde } \\
\text { (MAA) content and numyer } \\
\text { of bolls per plant }\end{array}$ & Liu et al, 2014 \\
\hline
\end{tabular}

Abbreviations: At - Arabidopsis thaliana; Ga - Gossypium arboroum; Gh - Gossypium hirsutum 